Kong. Res. J. 4(2): 95-126, 2017

ISSN 2349-2694

Kongunadu Arts and Science College, Coimbatore.

\title{
CHANGES IN SPECIES COMPOSITION AND ECOLOGICAL ATTRIBUTES OF PLANT SPECIES IN THE BRACHIARIA RAMOSA (STAPF.) DOMINATED GRASSLAND AS INFLUENCED BY DISTURBANCE
}

\author{
Abdul Kaffoor, H.,* A. Venkatachalapathi, S. Jamuna, K. Karthika and S. Paulsamy \\ Department of Botany, Kongunadu Arts and Science College, Coimbatore - 641 029, India. \\ *E.mail: kaffoorparakeet7@gmail.com
}

\begin{abstract}
The present study on the influence of disturbance in the dominated grassland near Bharathiar University, Coimbatore was studied over a period of one year from September, 2014 to August, 2015. The study was made during three seasons such as winter, summer and rainy so as to find out the seasonal changes as influenced by disturbance. The studied grassland is a semi-arid community containing most number of mesophytes with few xerophytes. To study the impact of disturbance, two sites such as undisturbed and disturbed ones spread over an area of 10 and 12 ha respectively were selected in the grassland. The floristic analysis showed that the undisturbed community was registered with 71 species and the disturbed community with 51 species. The family, Poaceae was represented by the high number of 14 and 13 species respectively in undisturbed and disturbed communities. Of the 71 species encounted, a sizable number of 66 species ( $92 \%$ ) harbour medicinal uses. It indicates that the study site was a potential habitat of medicinal plants with wide diversity. The quantitative ecological characters have been varied widely between the two sites due to the influence of disturbance. The resource apportionment for various species present in both study sites indicates that the grass, Brachiaria ramosa shared higher amount of resources than any other species present in the communities. The study suggested that the studied Brachiaria ramosa dominated grassland near Bharathiar University must be given conservation priority to protect the valuable medicinal species.
\end{abstract}

Keywords: Dominated grassland, Bharathiar University, Brachiaria racemosa.

\section{INTRODUCTION}

Grassland may be defined as a plant community which is dominated by perennial grasses, where there are few or no shrubs and trees are absent (Moore, 1964). Grasslands may be of two kinds, natural and artificial (Speeding, 1976). If origin is ignored, grasslands can be divided into cultivated and uncultivated (Davies, 1960). Grasslands are located across contrasting climatic and management gradients, which results in considerable variation in ecosystem structure, environmental conditions and disturbances regions (White et al., 2000; Gilmanov et al., 2010). The world's grasslands have been classified in many ways, chiefly on the basis of climatic factors (Moore, 1964) because this is often considered to be the major factor in determining the distribution of grasslands. Apart from the climate, edaphic, physiographic and the biotic factor, including fire play a major role in deciding the distribution of grasslands (Thomas, 1960). Throughout the world in the tropics, temperate and alpine regions the grassland occupy approximately 45.0 million sq.km. area and it is approximately $24 \%$ of the vegetation cover of the globe (Shantz, 1954). Based on the physiognomy and habitat, the grasslands of the world are classified under 7 types (Misra, 1968).

In tropical and subtropical India there are no examples of temperate or subtropical climax grassland and the typical tropical savannah type is also absent, the deciduous forest grading into thorn forest without any open park light stage. Even the alpine meadows are presumably secondary, owing to the existence of turf to grazing and lopping of the bushes. In the tropical zone grassland is common enough as a secondary seral stage and may be very stable preclimax under the influence of fire and grazing. In several regions of limited extent grassland also occurs as an edaphic climax. In all these cases the typical form is savannah or scrub, with or without scattered trees.

Grasslands of southern India exist due to biotic interferences, moisture stress, poor and shallow soils and long dry season on the plateau. Ranganathan (1938) considered the upland grass areas of Nilgiris as 'climatic climax' with species of Andropogon pertusus, Themeda imberbis, Cymbopogan polyneuros and Eragrostis nigra as common grasses. Meher - Homji (1969) has dicussed the phytogeographical aspects of the shola grasslands and considers frost as a controlling factor 
for the perpetuation of these grasslands. Bor (1938) opines that once that we admit the existence of grazing and burning in the area, we cannot apply the term 'climatic climax' and so these grasslands should be considered as biotic climax.

Ecological studies in grassland ecosystem are comparatively easier than those of forest ecosystem. Grasslands are easily manoeuvreable and are more uniform in physiognomy and composition which conditions provide ample opportunities for extensive ecological investigations. Besides, the grasslands have been the centre of agronomic and industrial activities of man and so study of this system has received his early attention. Phytosociological analysis of a plant community is the first and foremost basis of the study of any piece of vegetation as it is a pre-request to the understanding of community structure and organization. In the following account, a case study of grassland near Bharathiar University has been discussed. The study includes floristic composition, life-forms, ecologically important species, distribution level of constituent species, their numerical strength and cover, the relative importance of all constituent species, dominance and diversity of the community. The disturbance index has been calculated on basis of local biotic influence and it has been discussed with the species richness.

\section{MATERIALS AND METHODS}

\subsection{Description of study sites}

The present study sites the semiarid grasslands are located near Bharathiar University, Coimbatore at the latitude $11^{\circ} 13^{\prime} \mathrm{N}$ and the longitude $76^{\circ} 38^{\prime} \mathrm{E}$ at an elevation of $426 \mathrm{~m}$ above

M.S.L (Fig. 1). The undisturbed and the disturbed grassland taken for the present study are situated adjacently each other and they spread over an area of ca. 10ha (undisturbed) and ca.12ha (disturbed). The study was carried out for a period of 12 months from September, 2014 to August, 2015.

The climatic data of the study area is given in Table 1 . The temperature generally ranged between $17^{\circ} \mathrm{C}$ (January) and $36^{\circ} \mathrm{C}$ (March). During the study period the lowest and highest minimum temperatures have varied between 17.1 (January, 2015 ) and $22.9^{\circ} \mathrm{C}$ (August, 2015). On the other hand, the lowest and highest maximum temperatures have ranged between 27.9 (December, 2014 and $35.5^{\circ} \mathrm{C}$ (March, 2015). From January to March was a dry season and less rainfall occurred during April and May months. Adequate rainfall usually occurs from June through August during south- west monsoon. The north-east monsoon starts from October. The average rainfall for the past 20 years was as much as $600 \mathrm{~mm} /$ year. The relative humidity generally ranged from 80 (July) to $90 \%$ (December). The velocity of the wind was generally moderate.

The vegetation of the undisturbed study area was Brachiaria ramosa - dominated grassland composed by thirteen other grasses, one sedge and fifty six forbs. In disturbed study area, the same grass, Brachiaria ramosa was dominant and the associated species comprised twelve grasses, one sedges and thirty seven forbs. No natural woody vegetation was found in the study area. However, attempts were made to raise some tree species. The fauna of the region included some domestic animals like cattle, sheep, goats etc which usually graze on the pasture land. A few peacock, jackles, snakes, rats etc. were also found in the study area.

\subsection{Phytosociological studies}

The minimum quadrat size of $1 \times 1 \mathrm{~m}$ was fixed by the species - area curve method for phytosociological observations. Each time 100 quadrats were laid by the randomized method in each site. The minimum number of quadrat required (ie.100) was determined as described by Griez Smith (1964). For this, the mean number of individuals of the first two, four, six, eight and so on quadrat were calculated and plotted against the number of observations. It will be seen that the mean at first fluctuates, steadying as the required number of quadrats was reached.

The number and type of each species occurring in each quadrat were recorded. For grasses, each tiller was counted as an individual because it is impossible to decide from aerial shoots wheather it is separated or connected in the subterranean region, especially in perennial grasses. Different workers have used arbitrary units to represent individual. Armstrong (1907) and Stapledon (1913) have counted the entire individuals as far as possible in the case of erect plants, but in creeping grasses each rooting unit has taken as an individual. Stove and Fryer (1935) have considered an independent root system, as nearly as this could be determined without actually lifting the plant, to be a unit for counting. In the case of creeping plants, any portion of the plant upto $5 \mathrm{~cm}$ in length and having functional root was counted as one plant. Only the plants beyond seedling stage (ie., more than $2 \mathrm{~cm}$ height in case of monocots and beyond first leaf stage in dicots) were counted. The basal area at the point of emergence for the constituent species were measured. From the observations, the quantitative characters such as frequency, density, abundance, relative frequency, 
relative density, relative dominance, importance value index and relative value of importance were calculated.

Frequency, density and abundance were calculated using the following formulae:

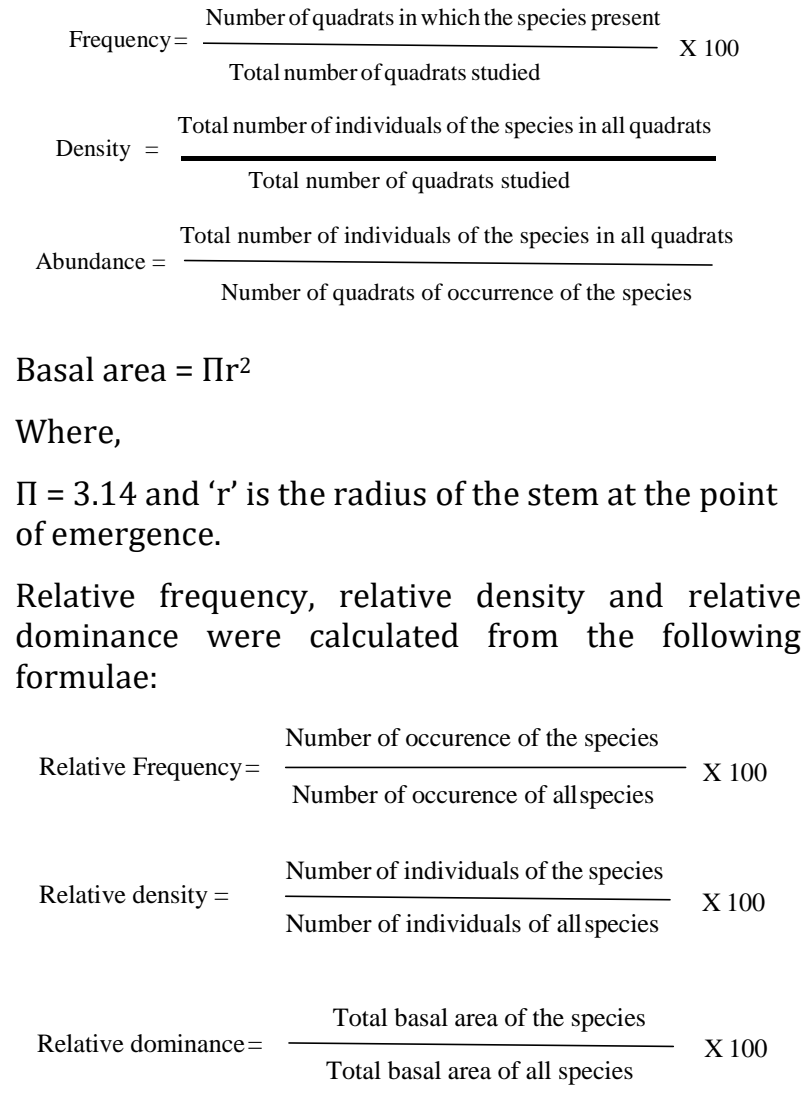

Relative frequency, relative density and relative dominance were calculated from the following formulae:

$$
\begin{aligned}
& \text { Relative Frequency }=\frac{\text { Number of occurence of the species }}{\text { Number of occurence of all species }} \times 100 \\
& \text { Relative density }=\frac{\text { Number of individuals of the species }}{\text { Number of individuals of all species }} \times 100 \\
& \text { Relative dominance }=\frac{\text { Total basal area of the species }}{\text { Total basal area of all species }} \times 100
\end{aligned}
$$

Important Value Index (I.V.I) is the sum of quantities of relative frequency, relative density and relative dominance expressed per 300.

Relative value of importance (RVI) was calculated by using the formula: $\mathrm{RVI}=\frac{\mathrm{IVI}}{3}$

The frequency index community coefficient (FICC) was calculated by using the formula as given by Gleason (1920):

$$
\text { FICC }=\frac{P}{Q} \times 100
$$

Where,

$$
\mathrm{P}={ }^{1} \overline{2} \text { of the frequencies of occurence of }
$$
common species.

$$
\mathrm{Q}={ }^{1} \overline{2} \text { of the frequencies of occurance of }
$$

common species $(\mathrm{P})+$ frequencies of occurance of exclusive species in all the four communities studied.

The similarity index (SI) has been calculated by the formula of Sorensen (1948):

$$
\mathrm{SI}=2 \mathrm{C} / \mathrm{A}+\mathrm{B}
$$

Where,

SI $=$ Similarity index

$\mathrm{C}=$ Number of common species in both the sites

$A$ and $B=$ Number of species in the $1^{\text {st }}$ and $2^{\text {nd }}$ sites respectively.

Dominance index was determined by the following formula as given by Simpson (1949):

$$
\mathrm{C}=\Sigma(\mathrm{ni} / \mathrm{N})^{2}
$$

Where,

$\mathrm{C}=$ Dominance index

$\mathrm{ni}=$ Number of individuals of a species over unit area

$\mathrm{N}=$ Corresponding total number of individuals of all species over the same unit area

$\Sigma=$ Summation

The Shannon - Wiener's index of species diversity was worked out by the following formula as given by Margelf (1968):

$$
\overline{\mathrm{H}}=\Sigma \mathrm{Pi} \ln \mathrm{Pi}
$$

Where,

H= Shannon - Wiener's index of species diversity

$\mathrm{Pi}=\mathrm{S} / \mathrm{N}$

$\mathrm{S}=$ Number of individuals of one species

$\mathrm{N}=$ Total number of all individuals in the sample

$\ln =$ The logrithim to the base ' $\mathrm{e}$ '

The disturbance index in both sites was calculated as per the method of Gunaga et al. (2013). To assess the biotic interference or the disturbance factors on vegetation, we considered scrapping, manual ploughing, litter collection, removal of soil, fire, gardening, grazing, building construction, trampling and collection of plants as the main parameters. For each site, the level of disturbance indicated by each of these ten parameters was scored from 0 (Undisturbed) to 3 (disturbed). The ten scores were added, and the sum multiplied by $100 / 30$ to give a percentage Combined Disturbance Index (CDI).

\section{RESULTS}

The present study on the sociological attributes of various plant species present in the Brachiaria ramosa dominated grassland community was carried out over a period of one year from September 2014 to August 2015. The influence of disturbance over the community composition was 
also assessed. The climatic data of the study area was given in Table 1. The range of temperature over the study period was existing between $17.1^{\circ} \mathrm{C}$ (January 2014) and $35.5^{\circ} \mathrm{C}$ (March 2015). The total rainfall during the study period of 2014-15 was $831.7 \mathrm{~mm} /$ year. Most of the rainfall was occurring during northeast monsoon (Oct - Dec). The south -west monsoon (June - July) was also brought certain rainfall but not at the level of north east monsoon during the study period. The relative humidity was always above 80 $\%$ with the peak of $90 \%$ during the month of December, 2014. The total number of plant species present in both the study areas was varying greatly higher number of 71 species was noted to be present in undisturbed site, whereas in the disturbed site, the species richness was drastically reduced through various anthropogenic activities to greater level of $28 \%$ loss.

The family-wise contribution of plant species to both disturbed and undisturbed study sites is given in Table 2. Among the 71 species present in the undisturbed site, a higher number of 14 species are belonging to the family, Poaceae. The other families such as Amaranthaceae and Euphorbiaceae have contributed 7 and 6 species respectively to the community. The remaining 20 families have contributed little number of less than 5 species only to the community. In the disturbed site, the Poaceae contributed the higher number of 13 species followed by Amaranthaceae with 6 species and Fabaceae and Convolvulaceae with 4 species each, the remaining 11 families contributed less number of species only to the disturbed community. The medicinal uses, parts used and mode of administration of various plants species present in both study area are given in Table 2 . Of the 71 species, 66 (92\%) harbour various medicinal uses. Majority of the plant species reported to have the medicinal uses for snake bite, kidney problem, hair growth, diabetes, jaundice and cancer. This wide usage of the plant species present in the study areas showed its potentiality for economic species.

The species composition during three different seasons such as winter (December), summer (March) and rainy (July) for the two study areas is given in Tables 3 and 4. Among the 71 species available in undisturbed site, 14 were grasses, 1 sedge and 56 forbs. In disturbed site, 13 were grasses, 1 sedge and 37 were forbs. The variation in species composition indicates that the members of Poaceae were known to be resistants against disturbance. Similarly the sedge, Cyperus rotundus was not distributed even in both sites. However, the forbs were disturbed drastically as 19 species such as Abutilon indicum, Aerva lanata , A. tomentosa, Alternanthera pungens, A. sessilis, Boerhaavia erecta, Cardiospermum halicacabum, Commelina benghalensis, Corchorus tridens, Euphorbia hirta, Evolvulus alsinoides, Ipomea dissecta, Leucas aspera, Mirabilis jalapa, Oldenlandia umbellata, Passiflora foetida, Phyllanthus amarus, $P$. maderaspatensis and Plumbago zeylanica have completely vanished in the disturbed site.

The quantitative ecological characters such as frequency, abundance, density and basal cover and synthetic characters such as relative frequency, relative density, relative dominance, importance value index and relative value of importance for all the study species present in the undisturbed and disturbed study sites for 3 different seasons are given in Tables 5 and 6 respectively. Generally, the grasses were disturbed more or less evenly in the respective communities than the sedges and forbs. In undisturbed site, the grasses like Brachiaria ramosa, Cynodon dactylon, Chloris barbata and Sporobolus heterolepis were distributed evenly than any other species in both the communities as they secured more than $50 \%$ of frequency value.

The sedge Cyperus rotundus, despite its consistency between the seasons in both study areas was determined to have restricted distribution. Among the forbs in undisturbed site, the species like Boerhaavia diffusa, Achyranthes aspera, Parthenium hysterophorus and Alysicarpus monilifer have higher frequency value than the rest of the species. However, in disturbed site, Parthenium hysterophorus was the only species having better distribution in terms of frequency percentage obtained. In general, it was observed that the rainy season was characterized by higher number of species with better distribution followed by winter and summer seasons. This fact shows that rainfall is the primary factor in this region having influence over the community composition and the distribution level as well.

In undisturbed site, the grasses such as Brachiaria ramosa, Chloris barbata, Cynodon dactylon and Sporobolus heterolepis and in forbs, the species like Aerva tomentosa, Alysicarpus monilifer, Gomphrena decumbens and Macrotyloma uniflorum have distributed abundantly than the other constituent species (Tables 5, 6 and 7). In the disturbed site, the same grass species as in undisturbed site and the forbs like Acalypha indica, Amaranthus spinosus, Bidens pilosa, Euphorbia hirta, Evolvulus nummularius, Indigofera enneaphylla, Macrotyloma uniflorum, Merremia tridentate, Spermacoce hispida and Trichodesma indica were present abundantly (Tables 8, 9 and 10). 
As determined for frequency, the grass species such as Brachiaria ramosa, Chloris barbata, Cyanodon dactylon and Sporobolus heterolepis were registered higher density in undisturbed site. In the similar fashion, the species like Achyranthes aspera, Alysicarpus monilifer, Boerrhavia diffusa, Euphorbia hirta, Parthenium hysterophorus, Tridax procumbens and Vernonia cinera were determined to have higher density among the forbs in undisturbed site. In disturbed site generally the density of all species were reduced greatly (Tables 8, 9 and 10). The species such as Brachiaria ramosa, Chloris barbata, Cyanodon dactylon and Sporobolus heterolepis were the species of higher densities in undisturbed site. The species like Alysicarpus monilifer, Euphorbia hirta, Tridax procumbens and Vernonia cinerea were registered comparatively higher density among the forbs in the disturbed site.

Based on the basal cover, the grass species, Brachiaria ramosa was considered to be the dominant species in both the undisturbed and disturbed sites (Tables 5-10). Between the three studied seasons this grass secured the basal cover of $124.62 \mathrm{~mm}^{2} / \mathrm{m}^{2}-245.92 \mathrm{~mm}^{2} / \mathrm{m}^{2}$. Similarly in undisturbed site, this grass species secured the basal cover between 29.57 and $95.05 \mathrm{~mm}^{2} / \mathrm{m}^{2}$. It shows that this grass species is a resistant against the various kinds of disturbances excerted over the community than the other species recorded in study site. Next to the dominant grass Brachiaria ramosa, the other perennial grass Chloris barbata occupied the high basal area in both study sites. When the forbs are considered altogether, this species such as Acalypha indica, Achyranthes aspera, Alysicarpus monilifer, Boerrhavia diffusa, Calotropis gigantea, Commelina benghalensis, Croton bonplandianum, Eupatorium odoratum, Gomphrena decumbens, Indigofera enneaphylla, Lantana camera, Parthenium hysterophorus, Solanum torvum, Tephrosia purpurea, Trichodesma indicum, Tridax procumbens and Vernonia cinerea were occupied higher basal cover than the other forbs in the undisturbed site (Tables 5-7). Similarly, in disturbed site also the species of forbs such as Achyranthes aspera, Alysicarpus monilifer, Boerrhavia diffusa, Calotropis gigantea, Commelina benghalensis, Croton bonplandianum, Eupatorium odoratum, Indigofera enneaphylla, Lantana camera, Parthenium hysterophorus, Datura metel, Trichodesma indicum, Tridax procumbens and Vernonia cinerea were have higher basal area (Tables 8-10).

The relative position of constituent species in terms of frequency, density and basal cover in the undisturbed and disturbed sites are presented in Tables 5-7 and 8-10 respectively. In undisturbed site the grass species such as Brachiaria ramosa, Chloris barbata, Cyanodon dactylon and Sporobolus heterolepis and the forbs such as Eupatorium odoratum, Achyranthes aspera, Alysicarpus monilifer, Boerrhavia diffusa, Euphorbia hirta, Parthenium hysterophorus, Tridax procumbens and Vernonia cinera were registered higher values of relative frequency, relative density and relative dominance. The same grasses such as Brachiaria ramosa, Chloris barbata, Cyanodon dactylon and Sporobolus heterolepis and the forbs such as Eupatorium odoratum, Achyranthes aspera, Alysicarpus monilifer, Boerrhavia diffusa, Euphorbia hirta, Lantana camera Parthenium hysterophorus, Tridax procumbens and Vernonia cinera have registered appreciated values of relative frequency, relative density and relative dominance. The same grass species mentioned for these relative values and the majority of the forbs mentioned for this purpose have in turn secured higher importance value index (IVI) (Tables 5-10) which indicates that all these species have received the maximum impact of environment in their respective site. The relative value of importance (RVI) was also determined to be higher for these mentioned species of higher IVI in their respective sites (Tables 5-10). The presence of higher ecological importance for these species in both sites showed that they are having well adaptive mechanism against the disturbance.

Table 1. Climatic data of the study area for the study period.

\begin{tabular}{ccccc}
\hline \multirow{2}{*}{$\begin{array}{c}\text { Year and } \\
\text { month }\end{array}$} & \multicolumn{2}{c}{$\begin{array}{c}\text { Temperature } \\
\left({ }^{\circ} \mathbf{C}\right)\end{array}$} & $\begin{array}{c}\text { Rainfall } \\
\text { (mm) }\end{array}$ & $\begin{array}{c}\text { Relative } \\
\text { humidity } \\
\text { (\%) }\end{array}$ \\
\cline { 2 - 3 } Max. & Min. & & \\
\hline Sep & 30.8 & 22.6 & 170.5 & 83 \\
Oct & 31.2 & 22.3 & 30.0 & 84 \\
Nov & 29.9 & 20.9 & 303.7 & 89 \\
Dec & 27.9 & 20.0 & 161.6 & 90 \\
2015 & & & & \\
Jan & 29.8 & 17.1 & - & 89 \\
Feb & 32.5 & 19.5 & 3.0 & 87 \\
Mar & 35.5 & 20.3 & - & 85 \\
Apr & 34.8 & 22.5 & 29.0 & 86 \\
May & 33.5 & 23.4 & 33.0 & 81 \\
Jun & 30.6 & 22.4 & 24.0 & 81 \\
Jul & 30.8 & 23.3 & 51.5 & 80 \\
Aug & 31.4 & 22.9 & 25.4 & 85 \\
\hline
\end{tabular}


Table 2. List of plant species with their families and their medicinal uses in the Brachiaria ramosadominated grassland.

\begin{tabular}{|c|c|c|c|c|}
\hline S.No. & Species & Family & Medicinal uses & Part used \\
\hline & \multicolumn{4}{|l|}{ Grasses } \\
\hline 1. & Andropogon virginicus & Poaceae & $\begin{array}{l}\text { A decoction of the roots is used in the treatment of backaches. A tea made } \\
\text { from the leaves is used in the treatment of diarrhea. Externally, it is used as } \\
\text { a wash for frostbite, sores, itching, piles and poison ivy rash. }\end{array}$ & $\begin{array}{l}\text { Root and } \\
\text { leaves }\end{array}$ \\
\hline 2. & Apluda mutica & Poaceae & Fodder & $\begin{array}{l}\text { Entire } \\
\text { Plant }\end{array}$ \\
\hline 5. & Cymbopogon caesius & Poaceae & Cereal and grass forages Forage plants. & Leaf \\
\hline 6. & Cynodon dactylon & Poaceae & $\begin{array}{l}\text { Eye disorders, weak vision, pungent, bitter, fragrant, heating, appetizer, } \\
\text { vulnerary, anthelmintic, antipyretic, alexiteric. It destroys foulness of } \\
\text { breath, useful in leucoderma, bronchitis, piles, asthma, tumors, and } \\
\text { enlargement of the spleen. Laxative, brain and heart tonic, aphrodisiac, } \\
\text { alexipharmic, emetic, emmenagogue, expectorant, carminative and useful } \\
\text { against grippe in children, and for pains, inflammations, and toothache; } \\
\text { palatable. }\end{array}$ & Stem and leaf \\
\hline 8. & Eragrostis aspera & Poaceae & Grains are eaten for asthma. & Grains \\
\hline 9. & Heteropogon contortus & Poaceae & In fever, muscle pain, atrophy and toothache, Asthma (Plant oil). & Whole plant \\
\hline 10. & Melinis repens & Poaceae & - & - \\
\hline 11. & Pennisetum alopecuroides & Poaceae & - & - \\
\hline 12. & Perotis indica & Poaceae & Good fodder. & Leaf \\
\hline 13. & Setaria pumila & Poaceae & $\begin{array}{l}\text { It can be eaten as a sweet or savoury food in all the ways that rice is used, } \\
\text { or ground into a powder and made into porridge, cakes, puddings etc. }\end{array}$ & Seed \\
\hline \multirow[t]{2}{*}{14.} & Sporobolus heterolepis & Poaceae & $\begin{array}{l}\text { Native Americans ground the seeds of the grass to make a tasty flour, and } \\
\text { many species of birds eat the seeds. }\end{array}$ & seeds \\
\hline & \multicolumn{4}{|l|}{ Sedges } \\
\hline
\end{tabular}




\section{Forbs}

16. Abutilon indicum

17. Acalypha indica

18. Achyranthes aspera

19. Aerva lanata

20. A. tomentosa

21. Alysicarpus monilifer

22. Alternanthera pungens
Malvaceae

Euphorbiaceae

Amaranthaceae

Pungent, laxative, stomachic, carminative and useful in the treatment of vomiting, bronchitis, heart diseases, piles, itching, abdominal pains, ascites, dyspepsia, dysentery, blood diseases etc. Useful for reclamation of wastelands. Leaf is consumed as pot herb. Seeds rich in protein, cooked and eaten. Used in religious ceremonies in India.

Amaranthaceae Diuretic and demulcent. The whole plant, especially the leaves are edible. The leaves are put into soup or eaten as spinach or as a vegetable. The plant provides grazing for stock, game in and chickens. A leaf- decoction is prepared as a gargle for treating sore-throat and used in various complex treatments against guinea-worm, smoke from the burning plant is inhaled The leaf-sap - eye-complaints; infusion - diarrhoea and in an unspecified manner at childbirth, and on sores; root is used in snake-bite treatment. For pains in the lower part of the back leaves and flowers are reduced to ash which is rubbed into cuts on the back.

Amaranthaceae Roots are chewed to form brush for cleaning teeth. Seeds are said to relieve head ache. They are also used against rheumatism. The herb is diuretic and demulcent. Its decoction is used to remove swellings.

Roots - for the treatment of leprosy and urinary troubles. The decoction of root is being used for cough. Boiled leaves purgative. It has antiproliferation activity against tumor cells. The whole plant - antipyretic, antiperiodic and has expectorant properties. The leaves -to treat jaundice and stomach pain. Leaf paste - for coetaneous problems.

Amaranthaceae Purification of blood, and all sorts of impurities, decongestant, diuretic, anti-inflammatory, anti liver ailments, kidney problems, diarrhea in whole plant

Leaf, root, stalks (young shoots) and

flower.

Leaf, seed

Leaf, root, flower.

Root and Seed

Leaf, stem, root, whole plant.

Leaf 
23. A. sessilis

24. Amaranthus spinosus

25. Bidens pilosa

26. b Boerhaavia erecta

27. B. diffusa

28. Calotropis gigantean

29. Cardiospermum halicacabum
.Amaranthaceae

Amaranthaceae

Asteraceae

Nyctaginaceae

Nyctaginaceae

Asclepiadaceae

Sapindaceae children and teething problems in children.

Diuretic, tonic and cooling. Juice of this plant deemed beneficial to eyes; an ingredient in the making of medicinal hair oils and used for simplestomach disorders, diarrhoea, dysentery and as a plaster for diseased or wounded skin parts and against fever, vomiting blood, headache and vertigo; Leaf sap is sniffed up the nose to treat neuralgia. Paste is used to draw out spines or any other object from the body and it is also used to cure hernia. Diabetes. The seed is used as a poultice for broken bones, internal bleeding, diarrhoea and excessive menstruation. Root - effective diuretic, gonorrhea, emmenagogue and antipyretic, toothaches. The bruised leaves are considered a good emollient and applied externally in cases of ulcerated mouths, eczema, burns, wounds, boils, earache and hemorrhoids. Leaves are also for gastroenteritis, gall bladder inflammation, abscesses, colic menorrhagia, arthritis and for the treatment of snakebites.

Antibacterial, antidysenteric, anti-inflammatory, antimicrobial, antimalarial, diuretic, hepato-protective and hypotensive activities.

Diuretic, stomachic, cardiotonic, hepatoprotective, laxative, anthelmintic, febrifuge, expectorant and, in higher doses, as an emetic and purgative. As a diuretic it is useful in cases of strangury, jaundice, enlarged spleen, gonorrhoea and other internal inflammations, asthma. Decoction of the whole plant - gastro-intestinal, liver and infertility problems and to treat convulsions in children. Paste of the root used to cure ulcers. Sap from the leaves is squeezed into the eye to treat conjunctivitis.

Cooling, astringent to bowels, useful in biliousness, blood purification, leucorrhoea, anaemia, inflammations, heart diseases and asthma. Leaves dyspepsia, tumours, spleen enlargement, abdominal pains. They are appetizer, alexiteric, in opthalmia,to treat joint pains. Seeds are tonic expectorant, carminative, useful in lumbago, scabies, and blood purifier.

Used to treat common diseases like fevers, rheumatism, indigestion, cough, cold, eczema, asthma, elephantiasis, nausea, vomiting, diarrhea etc. Dried whole plant is a good tonic, expectorant, depurative, and anthelmintic. The root bark is febrifuge, anthelmintic, depurative, expectorant and laxative. The powdered root used for asthma, bronchitis, and dyspepsia. Leaves for the treatment of paralysis, arthralegia, swellings and intermittent fevers. Flowers are bitter, digestive, astringent, stomachic, anthelmintic and tonic. It is used for arthritis and other painful conditions of the body. Theycan be used as a ear drops for ear ache, purulent discharge from ears. Root decoction can be given for haemorrhoids. Whole plant used for
Whole plant

Root, leaf, seed, tender shoot.

Leaves, Root and Seed.

Whole plant, Root, leaves.

Root, leaf, seed

Leaf, root bark, flower, seed.

Whole plant, Leaf. 
30. Cleome pentaphylla

31. Clitoria ternatea

32. Coccinia indica

33. Commelina benghalensis

34. Corchorus tridens

35. Crotalaria verrucosa

36. Croton bonplandianum

37. Datura metel
Capparidaceae

Fabaceae

Cucurbitaceae

Commelinaceae

Tiliaceae

Fabacaea

Euphorbiaceae

Solanaceae constipation and abdominal discomfort. The oil prepared from the paste of the leaves with gingilly oil can be used as a hair tonic and cure for dandruff.

Plant pacifies vitiated kapha, intestinal worms, colic, stomach upset, cardio myopathy, headache, diarrhea, fever and dyspepsia.

Blood purifier, abortifacient, astringent, demulcent, emetic, purgativeand in the treatment of anaemia, impetigo, menorrhagia and psoriasis. Seeds antispermatogenic, anti-ovulatory and contraceptive activities.

It is used to treat ring worm, psoriasis and itch; when mixed with ghee cures sores, skin diseases, skin eruptions of small pox; causes cooling effect to eyes, heals big ulcers, small lesions of scabies, anuria and alleviate body heat and has antispasmodic effect. Green fruit when chewed cures sores on tongue; raw fruit used as vegetable; dried fruit removes eczema. Dried bark has cathartic properties. Juice of tuberous roots, stem and leaves cure diabetes, intermittent glycosuria, enlarged glands and skin diseases like pityriasis and urinary tract infection. Used in treating gastro - intestinal disturbances, liver weakness, dysentery, vomiting, infestation, purifies blood, curb infection in the body, effective against chronic cough and cold and gives good results for bronchitis and asthma. Tubers remove pain in joints, diabetes, skin lesions (Tenia), apthous ulcers, wheezing and phlegm. Decoction of stem and leaf cures bronchitis.

For mouth thrush, inflammation of the conjunctiva, psychosis, epilepsy, nose blockage in children, insanity and exophthalmia; diuretic, febrifuge and anti- inflammatory; animal fodder, vegetable; laxative and to cure inflammations of the skin; leprosy.

Leaves - vegetable in stews eaten with starchy staple foods, and in soups and sauces.

Juice of leaves diminishes salivation, juice used for scabies andimpetigo, dyspepsia, blood impurities, diarrhea, dysentery, leprosy.

Whole plant has been credited with potential to cure liver diseases and swelling of the body, cure against ring worms and skin diseases. Bark and roots - alternative and chologogue. Leaves - controlling B.P and for the treatment of skin diseases and cut and wounds and it is antiseptic and antidote.

Seeds along with other substances are used as a remedy for the symptoms of madness based on homeopathic principle; decoction of seeds - eye diseases. The seeds - potential source for hyoscine, pain relief, asthma and other illnesses. The seed extract to treat wounds, tooth decay and leprosy due to hyoscine.
Whole plant

Seed, arial

parts

Leaf, stem, fruit, bark, root.

Whole plant

Leaf

leaves

Whole plant, Leaf, Bark, root.

Seeds, leaves, Flowers. 
38. Erigeron annuus

39. Eupatorium odoratum

40. Euphorbia hirta

41. E. microphylla

42. Evolvulus nummularis

43. E. alsinoides

44. Gomphrena decumbens

45. Heliotrophium indicum

46. Hibiscus vitifolius

47. Indigofera enneaphylla

48. Ipomea dissecta

49. I. obscura

50. Justicia tranquebariensis

51. Lantana camara
Asteraceae

Asteraceae

Euphorbiaceae

Euphorbiaceae

Convolvulaceae

Convolvulaceae

Amaranthaceae

Boraginaceae

Malvaceae

Convolvulaceae

Convolvulaceae

Convolvulaceae

Acanthaceae

Verbenaceae
Epilepsy, cough, cold, venereal disease, skin diseases.

It is good for colds. Boil the tea leaves in some water and serve as tea.

Sweeten with honey or as people do, serve with a dash of salt.

Decoction or infusion, to treat gastrointestinal disorders, including intestinal parasites, diarrhoea, peptic ulcers, heart burn, vomiting and amoebic dysentery. It is used to treat respiratory system disorders, including asthma, bronchitis, hay fever, laryngeal spasms, emphysema, coughs and colds. Leaves - diuretic to treat uro-genital like kidney stones, menstrual problems, sterility and venereal diseases. The plant is also used to treat infections of the skin and mucous membranes, including warts, scabies, tinea, thrush, aphthae, fungal afflictions, measles, Guinea -worm and as an antiseptic to treat wounds, sores and conjunctivitis. The plant has a reputation as an analgesic to treat severe headache, toothache, rheumatism, colic and pains during pregnancy; axial parts palatable.

Plant extract - jaundice; lower the elevated levels of serum bilirubin; antiulcer.

Cough cold, venereal disease, spermopiotic, fever, epilepsy, insanity, nervous debility, and loss of memory.

Roots - nerve tonic. Whole plant is widely used in ayurveda medicinal practice.

Plant part is used for the treatment of diabetes.

Treating abdominal pains, dysmenorrhoea, hypertension, convulsion, postpartum inflammatory disorders, wounds and infections and skin rashes.

Treatment of jaundice in the folklore system of medicine in India and antitubercular drug induced hepatotoxicity.

Wound healing.

Diuretic, fever, headache, pimples.

Diabetes, hypertension, dysentery, constipation, fatigue, arthritis, rheumatism, hydrocephaly, meningitis, kidney ailments andinflammations. Used in the traditional system of medicine for the treatment of fever, pain, inflammation, diabetes, diarrhea and liver diseases; antitumoral, antiviral, analgesic and anti-inflammatory activities.

Leaves - relieve itching, flu, colds, coughs, fevers, yellow fever, dysentery and jaundice. Roots - gonorrhea. Lantana oil - skin itches, antiseptic for
Root

Leaf

Leaf, tender

shoot

Leaf

Whole plant

Root, Whole

plant.

Whole plant

Whole plant

Root

Whole plant

Leaves and

Root.

Whole plant

Leaf

Leaf, bark, root, 


\section{Leucas aspera \\ 53. Macrotyloma uniflorum \\ 54. Martynia annua \\ 55. Meremmia emarginata \\ 56. M. tridentate \\ 57. Mirabilis jalapa}

\section{Oldenlandia umbellata \\ 59. Parthenium hysterophrous \\ 60. Passiflora foetida}

61. Pavonia indicum

62. Peristrophe bicalyculata

63. Phyllanthus amarus

64. P. maderaspatensis
Lamiaceae

Fabaceae

Martyniaceae

Convolvulaceae

Convolvulaceae

Nyctaginaceae

Rubiaceae

Asteraceae

Passifloraceae

Malvaceae

Acanthaceae

Euphorbiaceae

Euphorbiaceae wounds and externally for leprosy and scabies. Plant extracts - anticancers, chicken pox, measles, asthma, ulcers, swellings, eczema, tumors, high blood pressure, bilious fevers, catarrhal infections, tetanus, rheumatism, malaria and atoxy of abdominal viscera.

Nasal congestion, cough, cold, fever, headache.

Dysentery, venereal diseases, fever and diabetes.

Root decoction is administered for snakebite.Juice of leaf for epilepsy, tuberculosis and sorethroat. Stem of the plant is used by Tantriks in some parts of India.

-

Parts of the plant may be used as a diuretic, purgative, and for vulnerary purposes. The leaves are used to reduce inflammation. A decoction of leaf is used to treat abscesses. Leaf juice may be used to treat wounds.The root is believed an aphrodisiac as well as diuretic and purgative. It is used in the treatment of dropsy.

Decoction of the entire plant bronchial asthma. Decoction of the root is a febrifuge.

Decoction of root - dysentery; sub lethal doses of parthenium - antitumour activity.

Leaves and fruits - asthma and biliousness. Leaf and root decoction is emmenagogue, used in hysteria and leaf paste is applied on the head for giddiness and headache. The herb is used in the form of lotions or poultices for erysipelas and skin diseases with inflammation.

Nervous debility, hysteria and other nervous disorders and atomic dyspepsia.

Traditional healers are using this species in the treatment of many skin related problems; antidote for snake poison when macerated in an infusion of rice; insect repellant; used as horse feed; green manure; analgesic, antiinflammatory and antibacterial.

Hair, teeth, bones, kidneys, memory, sight, and hearing.

The plant sap and leaf decoction are credited with emetic and purgative activities. The whole plant is powdered and the solution is applied to scabies. Root decoction constipation, diarrhoea, appetite, intestinal pain, menstrual problems, gastrointestinal disorders, testicular swelling, chest complaints and snake bites. Gastrointestinal trouble in infants is treated by flowering

tops.

Whole plant

Leaves and

root.

Leaf, stem

root.

Leaf, root.

Whole plant

Root

Whole plant

Seed

Whole plant

Whole plant Whole plant, root. 


\section{Plumbago zeylanica}

66. Solanum torvum

67. Spermacoce hispida

68. Tephrosia purpurea

69. Trichodesma indicum

70. Tridax procumbens

71. Vernonia cinerea
Plumbaginaceae

Solanaceae

Rubiaceae

Fabaceae

Boraginaceae

Asteraceae

Asteraceae giving them a root decoction. Plant sap is used as no se drops to trea toothache. Ground leaves are rubbed on the skin with lemon juice to treatment for rheumatism; palatable.

treatment of toothache, applied externally to treat swellings, rheumatism, leprosy, tumors, and ringworm.

The juice to treat fever and alleviate pain; fruit - cosmetic; as rubbing its seeds on the cheeks helps remove freckles; diabetes liver-related ailments, jaundice; juice of the herb certain skin problems and tumors; decoction of the stalk, leaves, and roots - wounds and cancerous sores. Freshly prepared extract of the plant is effective in treating cirrhosis of the liver and also works as an antidote to poisoning by opium

Seeds - cooling, demulcent and given in diarrhea and dysentery; recommended as a substitute for coffee; Crushed into paste and taken orally to treat stomach problems; antihypertensive.

The plant is reported to cure diseases of the kidney, liver, spleen, heart and blood. The dried herb - tonic, laxative, and diuretic; Used in the treatment of bronchitis, bilious febrile attack, boils, pimples, and bleeding piles. The roots and seeds - insecticidal, pesticidal, and vermifugal properties; roots leprous wounds and root juice to skin eruptions. Aerial plant partsanticancer activity against a human nasopharyngeal epidermoid tumor cell line.

Leaves and roots are remedy for snake bites; diuretic. Cold infusion of leaves - depurative. Crushed roots, dysentery in children, diarrhea and fever, swollen joints, inflammations and superficial skin injuries; used for arthralgias, inflammations, dyspepsia, diarrhea, dysentery, dysmenorrhea. Plant pacifies vitiated pitta, inflammation, wound, ulcers, anal fistula, and hemorrhoids. Anticoagulant, antifungal and insect repellent; in bronchial catarrh, diarrhoea and dysentery. Wound healing activity and promotes hair growth.

Plant pacifies vitiated vata, pitta, tonsillitis, stomach pain, diarrhea, intermittent fever, eczema, herpes, ringworm, and elephantiasis. Leaves conjunctivitis and in lacrimation. Seeds - worm infestation, cough,

psoriasis, leukoderma and for other skin diseases. Plant possess anticancer property. Used for abortion, cancer and various gastrointestinal disorders.
Root

Fruit, whole plant.

Whole plant

Leaf, root, root bark, aerial parts, seed.

Root, leaf, flower.

Whole plant

Whole plant 
Table-3. Species with their individuals in undisturbed grassland during three different seasons.

\begin{tabular}{|c|c|c|c|c|c|c|c|c|c|}
\hline $\begin{array}{l}\text { S. } \\
\text { No }\end{array}$ & Species & $\begin{array}{l}\text { Winter } \\
\text { (Dec }\end{array}$ & $\begin{array}{c}\text { Summer } \\
\text { (Mar) }\end{array}$ & $\begin{array}{l}\text { Rainy } \\
\text { (Jul) }\end{array}$ & 31. & $\begin{array}{l}\text { Clitoria } \\
\text { ternatea }\end{array}$ & $4(3)$ & $3(3)$ & $5(4)$ \\
\hline & Grasses & & & & 32. & $\begin{array}{l}\text { Coccinia indica } \\
\text { Commelina }\end{array}$ & $2(1)$ & & $3(2)$ \\
\hline 1. & $\begin{array}{l}\text { Andropogon } \\
\text { virginicus }\end{array}$ & $12(4)$ & $10(2)$ & $21(6)$ & 33. & $\begin{array}{l}\text { Commellna } \\
\text { benghalensis } \\
\text { Corchorus }\end{array}$ & - & - & $3(2)$ \\
\hline 2. & $\begin{array}{l}\text { Apinad } \\
\text { mutica }\end{array}$ & $10(2)$ & $8(2)$ & $18(6)$ & 34. & tridens & - & - & $3(2)$ \\
\hline 3. & $\begin{array}{l}\text { Brachiaria } \\
\text { ramosa }\end{array}$ & $563(85)$ & $413(61)$ & $815(100)$ & 35. & $\begin{array}{l}\text { Crotalaria } \\
\text { verrucosa }\end{array}$ & - & - & $4(3)$ \\
\hline 4. & $\begin{array}{l}\text { Chloris } \\
\text { barbata } \\
\text { Cymbopogo }\end{array}$ & 598(79) & $411(55)$ & $965(100)$ & 36. & $\begin{array}{l}\text { Croton } \\
\text { bonplandianu } \\
m\end{array}$ & $6(2)$ & $3(1)$ & $16(9)$ \\
\hline 6. & $\begin{array}{l}\text { n caesius } \\
\text { Cynodon } \\
\text { dactylon }\end{array}$ & $996(84)$ & $632(71)$ & $\begin{array}{l}1332 \\
(100)\end{array}$ & $\begin{array}{l}37 . \\
38 .\end{array}$ & $\begin{array}{l}\text { Datura metel } \\
\text { Erigeron } \\
\text { annuus }\end{array}$ & $3(2)$ & $2(1)$ & $5(3)$ \\
\hline 7. & $\begin{array}{l}\text { Digitaria } \\
\text { eriantha } \\
\text { Eragrostis }\end{array}$ & $19(8)$ & $12(5)$ & $31(11)$ & 39. & $\begin{array}{l}\text { Eupatorium } \\
\text { odoratum }\end{array}$ & $15(6)$ & $8(3)$ & $26(16)$ \\
\hline 8. & $\begin{array}{l}\text { aspera } \\
\text { Heteropogo }\end{array}$ & $33(10)$ & $21(6)$ & $55(11)$ & $\begin{array}{l}40 . \\
41 .\end{array}$ & $\begin{array}{l}\text { hirta } \\
\text { E. microphylla }\end{array}$ & $36(10)$ & $21(8)$ & $52(20)$ \\
\hline 10 & $\begin{array}{l}n \text { contortus } \\
\text { Melinis }\end{array}$ & $8(3)$ & $6(3)$ & $32(9)$ & 42. & $\begin{array}{l}\text { Evolvulus } \\
\text { nummularius }\end{array}$ & $5(4)$ & $3(3)$ & $13(9)$ \\
\hline & $\begin{array}{l}\text { repens } \\
\text { Pennisetum }\end{array}$ & $9(2)$ & $6(2)$ & $16(3)$ & 43. & $\begin{array}{l}\text { E. alsinoides } \\
\text { Gomphrena }\end{array}$ & $11(6)$ & - & $21(10)$ \\
\hline 11. & $\begin{array}{l}\text { alopecoroid } \\
\text { es }\end{array}$ & $15(5)$ & $10(3)$ & $28(8)$ & 45 & $\begin{array}{l}\text { decumbens } \\
\text { Heliotrophium }\end{array}$ & $18(6)$ & $7(4)$ & $39(11)$ \\
\hline 12. & $\begin{array}{l}\text { Perotis } \\
\text { indica }\end{array}$ & $11(3)$ & $7(2)$ & $19(5)$ & 45. & $\begin{array}{l}\text { indicum } \\
\text { Hibiscus }\end{array}$ & $6(3)$ & - & $15(5)$ \\
\hline 13. & $\begin{array}{l}\text { Setaria } \\
\text { pumila }\end{array}$ & $89(26)$ & $75(16)$ & $120(48)$ & 47. & $\begin{array}{l}\text { vitifolius } \\
\text { Indigofera } \\
\text { enneaphylla }\end{array}$ & $?(11)$ & - & $2(2)$ \\
\hline 14. & $\begin{array}{l}\text { Sporobolus } \\
\text { heterolepis }\end{array}$ & $903(70)$ & $753(48)$ & $\begin{array}{l}1519 \\
(100)\end{array}$ & 48. & $\begin{array}{l}\text { Ipomea } \\
\text { dissecta }\end{array}$ & $26(11)$ & $9(16)$ & $40(25)$ \\
\hline 15. & $\begin{array}{l}\text { Sedges } \\
\text { Cyperus } \\
\text { rotundus }\end{array}$ & $16(9)$ & $13(4)$ & $43(18)$ & 49. & $\begin{array}{l}\text { I. obscura } \\
\text { Justicia }\end{array}$ & $2(1)$ & - & $\begin{array}{l}6(3) \\
5(3)\end{array}$ \\
\hline 16. & $\begin{array}{l}\text { Forbs } \\
\text { Abutilon } \\
\text { indicum }\end{array}$ & $2(2)$ & $2(1)$ & $5(4)$ & 50. & $\begin{array}{l}\text { tranquebariens } \\
\text { is }\end{array}$ & $4(2)$ & $2(1)$ & $8(5)$ \\
\hline 17. & & $3(2)$ & $2(2)$ & $19(9)$ & 51. & $\begin{array}{l}\text { Lantana } \\
\text { camara }\end{array}$ & $3(2)$ & $3(1)$ & $4(4)$ \\
\hline 18. & $\begin{array}{l}\text { indica } \\
\text { Achyranthes } \\
\text { aspera }\end{array}$ & $55(29)$ & $48(15)$ & $66(50)$ & 53. & $\begin{array}{l}\text { Leucas aspera } \\
\text { Macrotyloma } \\
\text { uniflorum }\end{array}$ & $7(3)$ & - & $14(6)$ \\
\hline 19. & $\begin{array}{l}\text { Aerva lanata } \\
\text { A. tomentosa }\end{array}$ & $\begin{array}{l}11(3) \\
8(2)\end{array}$ & $\begin{array}{l}- \\
5(2)\end{array}$ & $\begin{array}{l}18(6) \\
15(3)\end{array}$ & 54. & $\begin{array}{l}\text { Martynia } \\
\text { annua }\end{array}$ & $4(2)$ & $2(1)$ & $7(3)$ \\
\hline 21. & $\begin{array}{l}\text { Alysicarpus } \\
\text { monilifer }\end{array}$ & $34(12)$ & $24(10)$ & $71(19)$ & 55. & $\begin{array}{l}\text { Meremmia } \\
\text { emarginata }\end{array}$ & $5(2)$ & $3(1)$ & $11(4)$ \\
\hline 22. & $\begin{array}{l}\text { Alternanthera } \\
\text { pungens }\end{array}$ & $6(2)$ & $3(2)$ & $15(5)$ & 56. & $\begin{array}{l}\text { M. tridentata } \\
\text { Mirabilis }\end{array}$ & - & $2(1)$ & $6(3)$ \\
\hline 23. & A. sessilis & $5(3)$ & & $9(4)$ & & jalapa & $2(1)$ & $2(1)$ & $4(2)$ \\
\hline 24. & $\begin{array}{l}\text { Amaranthus } \\
\text { spinosus }\end{array}$ & $7(3)$ & $4(2)$ & $6(16)$ & 58. & $\begin{array}{l}\text { Oldenlandia } \\
\text { umbellata }\end{array}$ & - & - & $4(2)$ \\
\hline 25. & $\begin{array}{l}\text { Bidens pilosa } \\
\text { Boerhagia }\end{array}$ & $3(2)$ & $2(1)$ & $5(2)$ & 59. & Parthenium & $65(20)$ & $49(15)$ & $89(45)$ \\
\hline 26. & erecta & $2(4)$ & $2(1)$ & $3(8)$ & & $\begin{array}{l}\text { hysterophrous } \\
\text { Passiflora }\end{array}$ & & & \\
\hline 27. & B. diffusa & $54(40)$ & $43(15)$ & $89(63)$ & 60. & foetida & $2(1)$ & - & $3(3)$ \\
\hline 28. & Calotropis & $3(2)$ & $2(1)$ & $6(5)$ & 61. & Pavonia & - & - & $3(3)$ \\
\hline
\end{tabular}




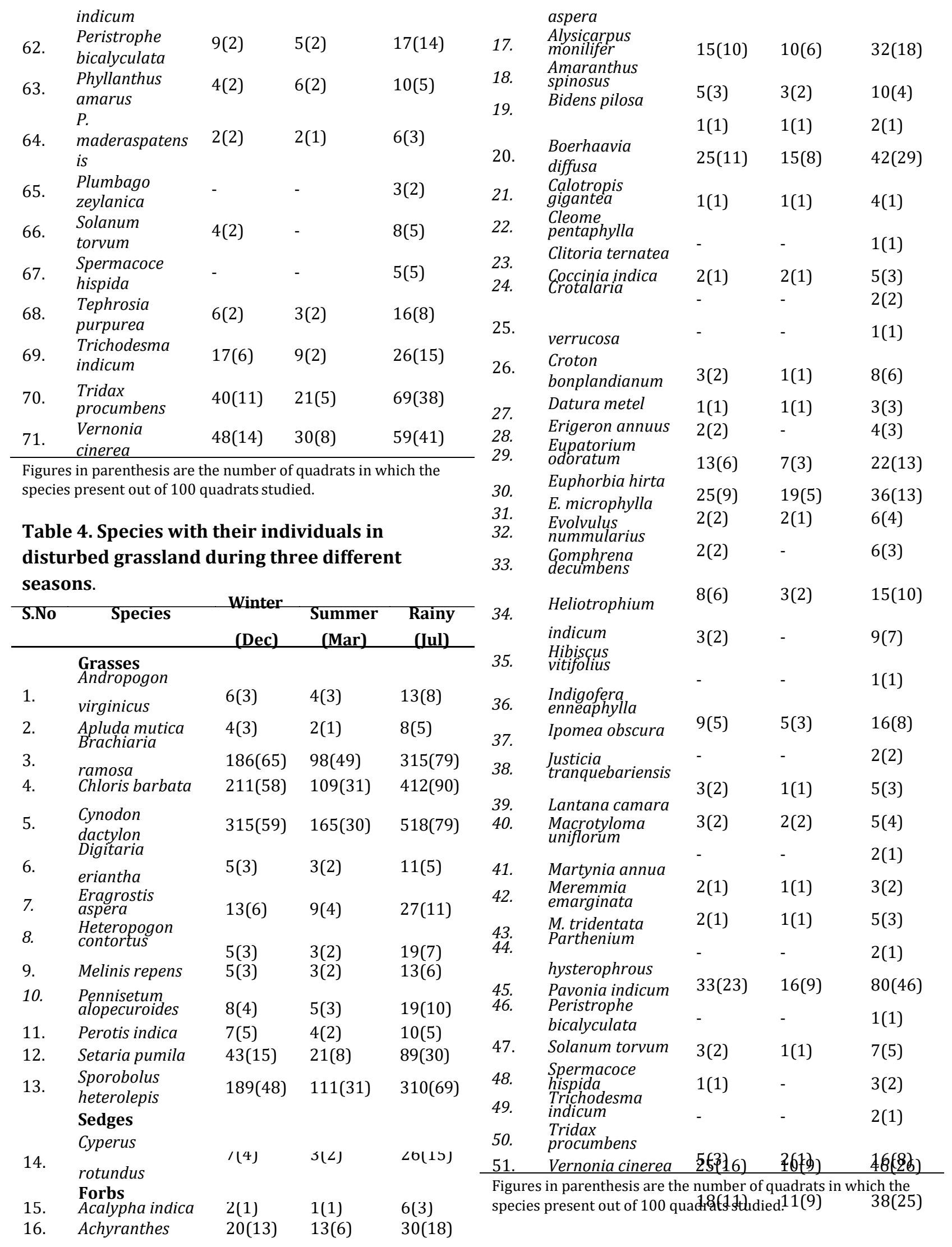


Table 5. Species composition in undisturbed grassland: frequency, abundance, density and basal cover and their relative values withimportance value index (IVI) and relative value of importance (RVI) during winter (Dec. 2014).

\begin{tabular}{|c|c|c|c|c|c|c|c|c|c|c|}
\hline \multirow[b]{2}{*}{ S.No } & \multirow[b]{2}{*}{ Species } & \multicolumn{4}{|c|}{ Quantitative attributes } & \multicolumn{5}{|c|}{ Synthetic attributes } \\
\hline & & $\begin{array}{c}\text { Frequency } \\
(\%)\end{array}$ & $\begin{array}{c}\text { Abundance } \\
\text { (individuals } / \mathbf{m}^{2} \text { ) }\end{array}$ & $\begin{array}{c}\text { Density } \\
\text { (individuals } / \mathrm{m}^{2} \text { ) }\end{array}$ & $\begin{array}{c}\text { Basal cover } \\
\left(\mathrm{mm}^{2} / \mathrm{m}^{2}\right)\end{array}$ & $\begin{array}{l}\text { R.F } \\
\text { (\%) }\end{array}$ & $\begin{array}{l}\text { R.DE } \\
\text { (\%) }\end{array}$ & $\begin{array}{l}\text { R.DO } \\
\text { (\%) }\end{array}$ & IVI & RVI \\
\hline & Grasses & & & & & & & & & \\
\hline 1. & Andropogan virginicus & 4 & 3 & 0.12 & 1.22 & 0.62 & 0.30 & 0.21 & 1.13 & 0.37 \\
\hline 2. & Apluda mutica & 2 & 5 & 0.1 & 1.38 & 0.31 & 0.25 & 0.24 & 0.79 & 0.26 \\
\hline 3. & Brachiaria ramose & 85 & 7 & 5.63 & 169.88 & 13.19 & 14.44 & 30.60 & 58.23 & 19.41 \\
\hline 5. & Cymbopogon caesius & 13 & 4 & 0.52 & 18.11 & 2.01 & 1.33 & 3.26 & 6.6 & 2.2 \\
\hline 6. & Cynodon dactylon & 84 & 11.85 & 9.96 & 20.01 & 13.04 & 25.55 & 3.60 & 42.19 & 14.06 \\
\hline 7. & Digitaria eriantha & 8 & 2.37 & 0.19 & 0.49 & 1.24 & 0.48 & 0.08 & 1.8 & 0.6 \\
\hline 8. & Eragrostis aspera & 10 & 3.3 & 0.33 & 1.04 & 1.55 & 0.84 & 0.18 & 2.57 & 0.85 \\
\hline 9. & Heteropogon contortus & 3 & 2.66 & 0.08 & 0.21 & 0.46 & 0.2 & 0.03 & 0.96 & 0.32 \\
\hline \multirow[t]{2}{*}{14.} & Sporobolusheterolepis & 70 & 12.9 & 9.03 & 22.97 & 10.86 & 23.17 & 4.13 & 38.26 & 12.75 \\
\hline & Sedges & & & & & & & & & \\
\hline \multirow[t]{2}{*}{15.} & Cyperus rotundus & 9 & 1.77 & 0.16 & 2.22 & 1.39 & 0.41 & 0.40 & 2.2 & 0.73 \\
\hline & Forbs & & & & & & & & & \\
\hline 16. & Abutilon indicum & 2 & 1 & 0.02 & 1.64 & 0.31 & 0.05 & 0.29 & 0.65 & 0.21 \\
\hline 17. & Acalypha indica & 2 & 1.5 & 0.03 & 1.37 & 0.31 & 0.07 & 0.25 & 0.63 & 0.21 \\
\hline 18. & Achyranthes aspera & 29 & 1.89 & 0.55 & 14.52 & 4.5 & 1.41 & 2.61 & 8.52 & 2.84 \\
\hline 19. & Aerva lanata & 3 & 3.66 & 0.11 & 1.39 & 0.46 & 0.28 & 0.25 & 0.99 & 0.33 \\
\hline 20. & A. tomentosa & 2 & 4 & 0.08 & 1.22 & 0.31 & 0.2 & 0.22 & 0.73 & 0.24 \\
\hline
\end{tabular}




\begin{tabular}{|c|c|c|c|c|c|c|c|c|c|c|}
\hline 21. & Alysicarpus monilifer & 12 & 2.83 & 0.34 & 5.65 & 1.86 & 0.87 & 1.01 & 3.74 & 1.24 \\
\hline 22. & Alternanthera pungens & 2 & 3 & 0.06 & 1.82 & 0.31 & 0.15 & 0.32 & 0.78 & 0.26 \\
\hline 23. & A. sessilis & 3 & 1.66 & 0.05 & 1.42 & 0.46 & 0.12 & 0.25 & 0.83 & 0.27 \\
\hline 24. & Amaranthus spinosus & 3 & 2.83 & 0.07 & 2.26 & 0.46 & 0.17 & 0.40 & 1.03 & 0.34 \\
\hline 25. & Bidens pilosa & 2 & 1.5 & 0.03 & 1.16 & 0.31 & 0.07 & 0.20 & 0.58 & 0.19 \\
\hline 26. & Boerhaavia erecta & 4 & 0.5 & 0.02 & 0.49 & 0.62 & 0.05 & 0.08 & 0.75 & 0.25 \\
\hline 27. & B. diffusa & 40 & 1.35 & 0.54 & 14.26 & 6.21 & 1.38 & 2.56 & 10.15 & 3.38 \\
\hline 28. & Calotropis gigantean & 2 & 1.5 & 0.03 & 6.03 & 0.31 & 0.07 & 1.08 & 1.46 & 0.48 \\
\hline 29. & $\begin{array}{l}\text { Cardiospermum } \\
\text { halicacabum }\end{array}$ & 2 & 1 & 0.02 & 0.77 & 0.31 & 0.05 & 0.13 & 0.49 & 0.16 \\
\hline 30. & Clitoria ternatea & 3 & 1.33 & 0.04 & 0.36 & 0.46 & 0.1 & 0.06 & 0.62 & 0.20 \\
\hline 31. & Coccinia indica & 1 & 2 & 0.02 & 0.28 & 0.15 & 0.05 & 0.05 & 0.25 & 0.08 \\
\hline 32. & Croton bonplandianum & 2 & 3 & 0.06 & 4.35 & 0.31 & 0.15 & 0.78 & 1.24 & 0.41 \\
\hline 33. & Datura metel & 2 & 1.5 & 0.03 & 6.49 & 0.31 & 0.07 & 1.16 & 1.54 & 0.51 \\
\hline 34. & Erigeron annus & 1 & 4 & 0.04 & 1.99 & 0.15 & 0.1 & 0.35 & 0.6 & 0.2 \\
\hline 35. & Eupatorium odoratum & 6 & 2.5 & 0.15 & 22.43 & 0.93 & 0.38 & 4.04 & 5.35 & 1.78 \\
\hline 36. & Euphorbia hirta & 10 & 3.6 & 0.36 & 1.14 & 1.55 & 0.92 & 0.20 & 2.67 & 0.89 \\
\hline 37. & E. microphylla & 4 & 1.25 & 0.05 & 0.08 & 0.62 & 0.12 & 0.01 & 0.75 & 0.25 \\
\hline 38. & Evolvulus nummularis & 3 & 2.66 & 0.08 & 0.37 & 0.46 & 0.2 & 0.06 & 0.72 & 0.24 \\
\hline 39. & E. alsinoides & 6 & 1.83 & 0.11 & 0.35 & 0.93 & 0.28 & 0.06 & 1.27 & 0.42 \\
\hline 40. & Gomphrena decumbens & 6 & 3 & 0.18 & 3.54 & 0.93 & 0.46 & 0.63 & 2.02 & 0.67 \\
\hline 41. & Heliotrophium indicum & 3 & 2 & 0.06 & 1.93 & 0.46 & 0.15 & 0.34 & 0.95 & 0.31 \\
\hline 42. & Indigofera enneaphylla & 11 & 2.36 & 0.26 & 8.36 & 1.7 & 0.66 & 1.50 & 3.86 & 1.28 \\
\hline 43. & Ipomea dissecta & 1 & 2 & 0.02 & 1.69 & 0.15 & 0.05 & 0.30 & 0.5 & 0.16 \\
\hline 44. & Justicia tranquebariensis & 2 & 2 & 0.04 & 1.92 & 0.31 & 38.97 & 0.34 & 39.62 & 13.20 \\
\hline 45. & Lantana camara & 2 & 1.5 & 0.03 & 10.58 & 0.31 & 0.07 & 1.90 & 2.28 & 0.76 \\
\hline 46. & Leucas aspera & 3 & 2.33 & 0.07 & 1.73 & 0.46 & 0.17 & 0.16 & 2.79 & 0.93 \\
\hline 47. & Martynia annua & 2 & 2 & 0.04 & 16.28 & 0.31 & 0.1 & 2.93 & 3.34 & 1.11 \\
\hline
\end{tabular}




\begin{tabular}{|c|c|c|c|c|c|c|c|c|c|c|}
\hline 48. & Meremmia emarginata & 2 & 2.5 & 0.05 & 2.52 & 0.31 & 0.12 & 0.45 & 0.88 & 0.29 \\
\hline 49. & Mirabilis jalapa & 1 & 2 & 0.02 & 1.06 & 0.15 & 0.05 & 0.19 & 0.39 & 0.13 \\
\hline 50. & $\begin{array}{l}\text { Parthenium } \\
\text { hysterophrous }\end{array}$ & 20 & 3.25 & 0.65 & 29.48 & 3.1 & 1.66 & 5.31 & 10.07 & 3.56 \\
\hline 51. & Passiflora foetida & 1 & 2 & 0.02 & 0.28 & 0.15 & 0.05 & 0.05 & 0.25 & 0.08 \\
\hline 52. & Peristrophe bicalyculata & 2 & 4.5 & 0.09 & 2.55 & 0.31 & 0.23 & 0.45 & 0.99 & 0.33 \\
\hline 53. & Phyllanthus amarus & 2 & 2 & 0.04 & 0.51 & 0.31 & 0.1 & 0.09 & 0.5 & 0.16 \\
\hline 54. & P. maderaspatensis & 2 & 1 & 0.02 & 0.49 & 0.31 & 0.05 & 0.08 & 0.44 & 0.14 \\
\hline 55. & Solanum torvum & 2 & 2 & 0.04 & 4.83 & 0.31 & 0.1 & 0.87 & 1.28 & 0.42 \\
\hline 56. & Tephrosia purpurea & 2 & 3 & 0.06 & 7.48 & 0.31 & 0.15 & 1.34 & 1.8 & 0.6 \\
\hline 57. & Trichodesma indicum & 6 & 2.83 & 0.17 & 8.12 & 0.93 & 0.43 & 1.46 & 2.82 & 0.94 \\
\hline 58. & Tridax procumbens & 11 & 3.63 & 0.4 & 19.11 & 1.7 & 1.02 & 3.44 & 6.16 & 2.05 \\
\hline 59. & Vernonia cinerea & 14 & 3.42 & 0.48 & 15.44 & 2.17 & 1.23 & 2.78 & 6.18 & 2.06 \\
\hline
\end{tabular}

R.F: Relative Frequency, R.DE: Relative Density, R.DO: Relative Dominance.

Table 6. Species composition in undisturbed grassland: frequency, abundance, density and basal cover and their relative values with importance value index (IVI) and relative value of importance (RVI) during summer (April,2015).

\begin{tabular}{|c|c|c|c|c|c|c|c|c|c|c|}
\hline \multirow[b]{2}{*}{ S.No } & \multirow[b]{2}{*}{ Species } & \multicolumn{4}{|c|}{ Quantitative attributes } & \multicolumn{5}{|c|}{ Synthetic attributes } \\
\hline & & $\begin{array}{c}\text { Frequency } \\
(\%)\end{array}$ & $\begin{array}{c}\text { Abundance } \\
\text { (individuals } / \mathbf{m}^{2} \text { ) }\end{array}$ & $\begin{array}{c}\text { Density } \\
\text { (individuals } / \mathbf{m}^{2} \text { ) } \\
\end{array}$ & $\begin{array}{c}\text { Basal cover } \\
\left(\mathrm{mm}^{2} / \mathbf{m}^{2}\right)\end{array}$ & $\begin{array}{l}\text { R.F } \\
(\%)\end{array}$ & $\begin{array}{c}\text { R.DE } \\
(\%)\end{array}$ & $\begin{array}{l}\text { K.NU } \\
\text { (\%) }\end{array}$ & IVI & RVI \\
\hline 1. & $\begin{array}{l}\text { Grasses } \\
\text { Andropogon virginicus } \\
\text { virginicus }\end{array}$ & 2 & 5 & 0.1 & 1.01 & 0.48 & 0.36 & 0.25 & 1.09 & 0.36 \\
\hline 2. & Apluda mutica & 2 & 4 & 0.08 & 1.1 & 0.48 & 0.29 & 0.27 & 1.04 & 0.34 \\
\hline 3. & Brachiaria ramose & 61 & 6.77 & 4.13 & 124.62 & 14.8 & 15.01 & 31.41 & 61.22 & 20.40 \\
\hline 5. & Cymbopogon caesius & 8 & 5 & 0.4 & 13.67 & 1.94 & 1.45 & 3.44 & 6.83 & 2.27 \\
\hline 6. & Cynodon dactylon & 71 & 8.9 & 6.32 & 12.7 & 17.23 & 22.98 & 3.20 & 43.41 & 14.47 \\
\hline 7. & Digitaria eriantha & 5 & 2.4 & 0.12 & 0.3 & 1.21 & 0.43 & 0.07 & 1.71 & 0.57 \\
\hline 8. & Eragrostis aspera & 6 & 3.5 & 0.21 & 0.65 & 1.45 & 0.76 & 0.16 & 2.37 & 0.79 \\
\hline
\end{tabular}




\begin{tabular}{|c|c|c|c|c|c|c|c|c|c|c|}
\hline 9. & Heteropogon contortus & 3 & 2 & 0.06 & 0.15 & 0.72 & 0.21 & 0.03 & 0.96 & 0.32 \\
\hline 10. & Melinis repens & 2 & 3 & 0.06 & 0.12 & 0.48 & 0.21 & 0.03 & 0.72 & 0.24 \\
\hline 11. & Pennisetumalopecuroides & 3 & 3.33 & 0.1 & 0.45 & 0.72 & 0.36 & 0.11 & 1.19 & 0.39 \\
\hline 12. & Perotis indica & 2 & 3.5 & 0.07 & 0.37 & 0.48 & 0.25 & 0.09 & 0.82 & 0.27 \\
\hline 13. & Setaria pumila & 16 & 4.68 & 0.75 & 3.39 & 3.88 & 2.72 & 0.85 & 7.43 & 2.48 \\
\hline \multirow[t]{2}{*}{14.} & Sporobolus heterolepis & 48 & 15.68 & 7.53 & 19.15 & 11.65 & 27.38 & 4.82 & 43.85 & 14.61 \\
\hline & Sedges & & & & & & & & & \\
\hline \multirow[t]{2}{*}{15.} & Cyperus rotundus & 4 & 3.25 & 0.13 & 1.86 & 0.97 & 0.07 & 0.46 & 1.50 & 0.5 \\
\hline & Forbs & & & & & & & & & \\
\hline 16. & Abutilon indicum & 1 & 2 & 0.02 & 1.63 & 0.24 & - & 0.41 & 0.65 & 0.21 \\
\hline 17. & Acalypha indica & 2 & 1 & 0.02 & 0.9 & 0.48 & 0.07 & 0.22 & 0.77 & 0.25 \\
\hline 18. & Achyranthes aspera & 15 & 3.2 & 0.48 & 12.67 & 3.64 & 1.74 & 3.19 & 8.57 & 2.85 \\
\hline 19. & Aerva tomentosa & 2 & 2.5 & 0.05 & 0.75 & 0.48 & 0.18 & 0.18 & 0.84 & 0.28 \\
\hline 20. & Alysicarpus monilifer & 10 & 2.4 & 0.24 & 3.98 & 2.42 & 0.77 & 1 & 4.19 & 1.39 \\
\hline 21. & Alternanthera pungens & 2 & 1.5 & 0.03 & 0.9 & 0.48 & 0.1 & 0.22 & 0.80 & 0.26 \\
\hline 22. & Amaranthus spinosus & 2 & 2 & 0.04 & 1.28 & 0.48 & 0.14 & 0.32 & 0.94 & 0.31 \\
\hline 23. & Bidens pilosa & 1 & 2 & 0.02 & 0.76 & 0.24 & 0.07 & 0.19 & 0.50 & 0.16 \\
\hline 24. & Boerhaavia erecta & 1 & 2 & 0.02 & 0.49 & 0.24 & 0.07 & 0.12 & 0.43 & 0.14 \\
\hline 25. & B. diffusa & 15 & 2.86 & 0.43 & 11.35 & 1.64 & 1.56 & 2.86 & 6.06 & 2.02 \\
\hline 26. & Calotropis gigantean & 1 & 2 & 0.02 & 4.01 & 0.24 & 0.07 & 1.01 & 1.32 & 0.44 \\
\hline 27. & Clitoria ternatea & 3 & 3 & 0.03 & 0.73 & 0.72 & 0.1 & 0.18 & 1.0 & 0.33 \\
\hline 28. & Croton bonplandianum & 1 & 3 & 0.03 & 2.17 & 0.24 & 0.1 & 0.54 & 0.88 & 0.29 \\
\hline 29. & Datura metal & 1 & 2 & 0.02 & 4.32 & 0.24 & 0.07 & 1.08 & 1.39 & 0.46 \\
\hline 30. & Eupatorium odoratum & 3 & 2.66 & 0.08 & 11.98 & 0.72 & 0.29 & 3.01 & 4.02 & 1.34 \\
\hline 31. & Euphorbia hirta & 8 & 2.62 & 0.21 & 0.65 & 1.94 & 0.76 & 0.16 & 2.86 & 0.95 \\
\hline 32. & E. microphylla & 3 & 1 & 0.03 & 0.04 & 0.72 & 0.1 & 0.01 & 0.83 & 0.27 \\
\hline 33. & Gomphrena decumbens & 4 & - & 0.07 & 1.37 & 0.97 & 0.25 & 0.34 & 1.56 & 0.52 \\
\hline 34. & Indigofera enneaphylla & 6 & 1.5 & 0.09 & 32.15 & 1.45 & 0.32 & 8.10 & 9.87 & 3.29 \\
\hline
\end{tabular}




\begin{tabular}{|c|c|c|c|c|c|c|c|c|c|c|}
\hline 35. & Justicia tranquebariensis & 1 & 2 & 0.02 & 0.95 & 0.24 & 0.07 & 0.23 & 0.54 & 0.18 \\
\hline 36. & Lantana camara & 1 & 3 & 0.03 & 10.58 & 0.24 & 0.1 & 2.66 & 3.0 & 1.0 \\
\hline 37. & Martynia annua & 1 & 2 & 0.02 & 0.81 & 0.24 & 0.07 & 0.20 & 0.51 & 0.17 \\
\hline 38. & Meremmia emarginata & 1 & 3 & 0.03 & 1.5 & 0.24 & 0.1 & 0.03 & 0.37 & 0.12 \\
\hline 39. & M. tridentate & 1 & 2 & 0.02 & 0.9 & 0.24 & 0.07 & 0.22 & 0.53 & 0.17 \\
\hline 40. & Mirabilis jalapa & 1 & 2 & 0.02 & 1.05 & 0.24 & 0.07 & 0.26 & 0.57 & 0.19 \\
\hline 41. & Parthenium hysterophorus & 15 & 3.26 & 0.49 & 22.21 & 3.64 & 1.78 & 5.59 & 11.0 & 3.66 \\
\hline 42. & Peristrophe bicalyculata & 2 & 2.5 & 0.05 & 1.41 & 0.48 & 0.18 & 0.35 & 1.01 & 0.33 \\
\hline 43. & Phyllanthus amarus & 2 & 3 & 0.06 & 0.25 & 0.48 & 0.21 & 0.06 & 0.75 & 0.25 \\
\hline 44. & P. maderaspatensis & 1 & 2 & 0.02 & 0.49 & 0.24 & 0.07 & 0.12 & 0.43 & 0.14 \\
\hline 45. & Tephrosia purpurea & 2 & 1.5 & 0.03 & 3.73 & 0.48 & 0.1 & 0.94 & 1.52 & 0.50 \\
\hline 46. & Trichodesma indicum & 2 & 4.5 & 0.09 & 4.29 & 0.48 & 0.32 & 1.08 & 1.88 & 0.62 \\
\hline 47. & Tridax procumbens & 5 & 4.2 & 0.21 & 10.02 & 1.21 & 0.76 & 2.52 & 4.49 & 1.49 \\
\hline 48. & Vernonia cinerea & 8 & 3.75 & 0.31 & 9.96 & 1.94 & 1.12 & 2.51 & 5.57 & 1.85 \\
\hline
\end{tabular}

R.F: Relative Frequency, R.DE: Relative Density, R. DO: Relative Dominance.

Table 7. Species composition in undisturbed grassland: frequency, abundance, density and basal cover and their relative values with importance value index (IVI) and relative value of importance (RVI) during rainy (July,2015).

\begin{tabular}{|c|c|c|c|c|c|c|c|c|c|c|}
\hline \multirow[b]{2}{*}{ S.No } & \multirow[b]{2}{*}{ Species } & \multicolumn{4}{|c|}{ Quantitative attributes } & \multicolumn{5}{|c|}{ Synthetic attributes } \\
\hline & & $\begin{array}{c}\text { Frequency } \\
\text { (\%) }\end{array}$ & $\begin{array}{c}\text { Abundance } \\
\text { (individuals } / \mathrm{m}^{2} \text { ) }\end{array}$ & $\begin{array}{c}\text { Density } \\
\text { (individuals/ } \\
\mathbf{m}^{\mathbf{2}} \text { ) } \\
\end{array}$ & $\begin{array}{c}\text { Basal } \\
\text { cover } \\
\left(\mathrm{mm}^{2} / \mathrm{m}^{2}\right)\end{array}$ & R.F (\%) & $\begin{array}{l}\text { R.DE } \\
(\%)\end{array}$ & $\begin{array}{c}\text { R.DO } \\
\text { (\%) }\end{array}$ & IVI & RVI \\
\hline & Grasses & & & & & & & & & \\
\hline 1. & $\begin{array}{l}\text { Andropogon virginicus } \\
\text { virginicus }\end{array}$ & 6 & 3.5 & 0.21 & 2.13 & 0.54 & 0.34 & 0.23 & 1.11 & 0.37 \\
\hline 2. & Apluda mutica & 6 & 3 & 0.18 & 2.49 & 0.54 & 0.29 & 0.27 & 1.1 & 0.36 \\
\hline 3. & Brachiariaramose & 100 & 8.15 & 8.15 & 245.92 & 9.09 & 13.35 & 27.42 & 49.86 & 16.62 \\
\hline 4. & Chloris barbata & 100 & 9.65 & 9.65 & 133.62 & 9.09 & 15.8 & 14.9 & 39.79 & 13.26 \\
\hline 5. & Cymbopogon caesius & 18 & 4.22 & 0.76 & 25.98 & 1.63 & 1.24 & 2.89 & 5.76 & 1.92 \\
\hline 6. & Cynodon dactylon & 100 & 13.32 & 13.32 & 26.76 & 9.09 & 21.8 & 2.98 & 33.87 & 11.29 \\
\hline
\end{tabular}




\begin{tabular}{|c|c|c|c|c|c|c|c|c|c|c|}
\hline 7. & Digitaria eriantha & 11 & 2.81 & 0.31 & 0.78 & 1 & 0.5 & 0.08 & 1.58 & 0.52 \\
\hline 8. & Eragrostis aspera & 11 & 5 & 0.55 & 1.72 & 1 & 0.9 & 0.19 & 2.09 & 0.69 \\
\hline 9. & Heteropogon contortus & 9 & 3.55 & 0.32 & 0.81 & 0.81 & 0.52 & 0.09 & 1.42 & 0.47 \\
\hline 10. & Melinis repens & 3 & 5.33 & 0.16 & 0.32 & 0.27 & 0.2 & 0.03 & 0.5 & 0.16 \\
\hline 11. & Pennisetumalopecuroides & 8 & 3.5 & 0.28 & 1.26 & 0.72 & 0.45 & 1.41 & 2.58 & 0.86 \\
\hline 12. & Perotis indica & 5 & 3.8 & 0.19 & 1.01 & 0.45 & 0.31 & 0.11 & 0.87 & 0.29 \\
\hline 13. & Setaria pumila & 48 & 2.5 & 1.2 & 5.42 & 4.36 & 1.96 & 0.6 & 6.92 & 2.30 \\
\hline \multirow[t]{2}{*}{15.} & Cyperus rotundus & 18 & 2.38 & 0.43 & 5.95 & 1.63 & 0.7 & 0.66 & 2.99 & 0.99 \\
\hline & Forbs & & & & & & & & & \\
\hline 16. & Abutilon indicum & 4 & 1.25 & 0.05 & 4.08 & 0.36 & 0.08 & 0.45 & 0.89 & 0.29 \\
\hline 17. & Acalypha indica & 9 & 2.11 & 0.19 & 8.61 & 0.81 & 0.31 & 0.96 & 2.08 & 0.69 \\
\hline 22. & Alternanthera pungens & 5 & 3 & 0.15 & 4.52 & 0.45 & 0.24 & 0.5 & 1.19 & 0.39 \\
\hline 23. & A. sessilis & 4 & 2.25 & 0.09 & 2.54 & 0.36 & 0.14 & 0.28 & 0.78 & 0.26 \\
\hline 24. & Amaranthus spinosus & 16 & 0.37 & 0.06 & 1.92 & 1.45 & 0.09 & 0.21 & 1.75 & 0.58 \\
\hline 25. & Bidens pilosa & 2 & 2.5 & 0.05 & 1.92 & 0.18 & 0.08 & 0.21 & 0.47 & 0.15 \\
\hline 26. & Boerhaavia erecta & 8 & 0.37 & 0.03 & 0.73 & 0.72 & 0.04 & 0.08 & 0.84 & 0.28 \\
\hline 27. & B. diffusa & 63 & 1.41 & 0.89 & 23.5 & 5.73 & 1.45 & 2.62 & 9.8 & 3.26 \\
\hline 28. & Calotropis gigantean & 5 & 1.2 & 0.06 & 12.05 & 0.45 & 0.09 & 1.34 & 1.88 & 0.62 \\
\hline 29. & $\begin{array}{l}\text { Cardiospermum } \\
\text { halicacabum }\end{array}$ & 3 & 1.33 & 0.04 & 1.53 & 0.27 & 0.06 & 0.17 & 0.5 & 0.16 \\
\hline 30. & Cleome pentaphylla & 2 & 2.5 & 0.05 & 0.98 & 0.18 & 0.08 & 0.1 & 0.36 & 0.12 \\
\hline
\end{tabular}




\begin{tabular}{|c|c|c|c|c|c|c|c|c|c|c|}
\hline 32. & Coccinia indica & 2 & 1.5 & 0.03 & 0.41 & 0.18 & 0.04 & 0.04 & 0.26 & 0.08 \\
\hline 33. & Commelina benghalensis & 2 & 1.5 & 0.16 & 8.15 & 0.18 & 0.26 & 0.9 & 1.34 & 0.44 \\
\hline 34. & Corchorus tridens & 2 & 1.5 & 0.03 & 0.79 & 0.18 & 0.04 & 0.08 & 0.3 & 0.1 \\
\hline 35. & Crotalaria verrucosa & 3 & 1.33 & 0.04 & 3.93 & 0.27 & 0.06 & 0.43 & 0.76 & 0.25 \\
\hline 36. & Croton bonplandianu & 9 & 1.77 & 0.16 & 11.57 & 0.81 & 0.26 & 1.29 & 2.36 & 0.78 \\
\hline 37. & Datura metal & 3 & 1.75 & 0.05 & 10.81 & 0.27 & 0.08 & 1.2 & 1.55 & 0.51 \\
\hline 38. & Erigeron annus & 4 & 1.62 & 0.07 & 3.34 & 0.36 & 0.11 & 0.37 & 0.84 & 0.28 \\
\hline 39. & Eupatorium odoratum & 16 & 1.62 & 0.26 & 38.86 & 1.45 & 0.42 & 4.33 & 6.2 & 2.06 \\
\hline 40. & Euphorbia hirta & 20 & 2.6 & 0.52 & 1.63 & 1.81 & 0.85 & 0.18 & 2.84 & 0.94 \\
\hline 41. & E. microphylla & 9 & 1.44 & 0.13 & 0.2 & 0.81 & 0.21 & 0.02 & 1.04 & 0.34 \\
\hline 42. & Evolvulus nummularis & 5 & 2.6 & 0.13 & 0.58 & 0.45 & 0.21 & 0.06 & 0.72 & 0.24 \\
\hline 43. & E. alsinoides & 10 & 2.1 & 0.21 & 0.65 & 0.9 & 0.34 & 0.07 & 1.31 & 0.43 \\
\hline 44. & Gomphrena decumbens & 11 & 3.54 & 0.39 & 7.65 & 0.18 & 0.63 & 0.85 & 1.66 & 0.55 \\
\hline 45. & Heliotrophium indicum & 5 & 3 & 0.15 & 4.82 & 0.45 & 0.24 & 0.53 & 1.22 & 0.40 \\
\hline 46. & Hibiscus vitifolius & 2 & 1 & 0.02 & 2.49 & 0.18 & 0.03 & 0.27 & 0.48 & 0.16 \\
\hline 47. & Indigofera enneaphylla & 25 & 2 & 0.4 & 12.86 & 2.27 & 0.65 & 1.43 & 4.35 & 1.45 \\
\hline 48. & Ipomea dissecta & 3 & 2 & 0.06 & 5.09 & 0.27 & 0.09 & 0.56 & 0.92 & 0.30 \\
\hline 49. & I.obscura & 3 & 1.66 & 0.05 & 3.61 & 0.27 & 0.08 & 0.4 & 0.75 & 0.25 \\
\hline 50. & Justicia tranquebariensis & 5 & 1.6 & 0.08 & 3.82 & 0.45 & 0.13 & 0.42 & 1 & 0.33 \\
\hline 51. & Lantana camara & 4 & 1 & 0.04 & 14.11 & 0.36 & 0.06 & 1.57 & 1.99 & 0.66 \\
\hline 52. & Leucas aspera & 6 & 2.33 & 0.14 & 3.44 & 0.54 & 0.22 & 0.38 & 1.14 & 0.38 \\
\hline 53. & Macrotyloma uniflorum & 3 & 2.75 & 0.05 & 1.92 & 0.27 & 0.08 & 0.21 & 0.56 & 0.18 \\
\hline 54. & Martynia annua & 3 & 2 & 0.07 & 2.84 & 0.27 & 0.11 & 0.31 & 0.69 & 0.23 \\
\hline 55. & Meremmia emarginata & 4 & 2 & 0.11 & 5.52 & 0.36 & 0.18 & 0.61 & 1.15 & 0.38 \\
\hline 56. & M.tridentate & 3 & 2 & 0.06 & 2.72 & 0.27 & 0.09 & 0.3 & 0.66 & 0.22 \\
\hline 57. & Mirabilis jalapa & 2 & 1.97 & 0.04 & 2.11 & 0.18 & 0.06 & 0.23 & 0.47 & 0.15 \\
\hline 58. & Oldenlandia umbellata & 2 & 2 & 0.04 & 0.1 & 0.18 & 0.06 & 0.02 & 0.26 & 0.08 \\
\hline 59. & Parthenium hysterophorus & 45 & 1.97 & 0.89 & 40.35 & 4.09 & 1.45 & 4.49 & 10.03 & 3.34 \\
\hline
\end{tabular}




\begin{tabular}{|c|c|c|c|c|c|c|c|c|c|c|}
\hline 60. & Passiflora foetida & 3 & 1 & 0.03 & 0.41 & 0.27 & 0.04 & 0.04 & 0.35 & 0.11 \\
\hline 61. & Pavonia indicum & 3 & 1 & 0.03 & 1.15 & 0.27 & 0.04 & 0.12 & 0.43 & 0.14 \\
\hline 62. & Peristrophe bicalyculata & 14 & 1.21 & 0.17 & 4.8 & 1.27 & 0.27 & 0.52 & 2.06 & 0.68 \\
\hline 63. & Phyllanthus amarus & 5 & 2 & 0.1 & 1.25 & 0.45 & 0.16 & 0.13 & 0.74 & 0.24 \\
\hline 64. & P. maderaspatensis & 3 & 2 & 0.06 & 1.47 & 0.27 & 0.09 & 0.16 & 0.52 & 0.17 \\
\hline 65. & Ricinus communis & 2 & 1.5 & 0.03 & 1.5 & 0.18 & 0.04 & 0.16 & 0.38 & 0.38 \\
\hline 66. & Solanum torvum & 5 & 1.6 & 0.08 & 9.65 & 0.45 & 0.13 & 1.07 & 1.65 & 0.55 \\
\hline 67. & Spermacoce hispida & 5 & 1 & 0.05 & 4.41 & 0.45 & 0.08 & 0.49 & 1.02 & 0.34 \\
\hline 68. & Tephrosia purpurea & 8 & 2 & 0.16 & 19.94 & 0.72 & 0.26 & 2.22 & 3.2 & 1.06 \\
\hline 69. & Trichodesma indicum & 15 & 1.73 & 0.26 & 12.41 & 1.36 & 0.42 & 1.38 & 3.16 & 1.05 \\
\hline 70. & Tridax procumbens & 38 & 1.81 & 0.69 & 32.95 & 3.45 & 1.13 & 3.67 & 8.25 & 2.75 \\
\hline 71. & Vernonia cinerea & 41 & 1.43 & 0.69 & 22.18 & 3.73 & 1.13 & 2.47 & 7.33 & 2.44 \\
\hline
\end{tabular}

R.F: Relative Frequency, R.DE: Relative Density, R. DO: Relative Dominance.

Table 8. Species composition in disturbed grassland: frequency, abundance, density and basal cover and their relative values with importance value index (IVI) and relative value of importance (RVI) during winter (Dec. 2014).

\begin{tabular}{|c|c|c|c|c|c|c|c|c|c|c|}
\hline \multirow[b]{2}{*}{ S.No } & \multirow[b]{2}{*}{ Species } & \multicolumn{4}{|c|}{ Quantitative attributes } & \multicolumn{5}{|c|}{ Synthetic attributes } \\
\hline & & Frequency (\%) & $\begin{array}{c}\text { Abundance } \\
\text { (individuals } / \mathbf{m}^{2} \text { ) }\end{array}$ & $\begin{array}{c}\text { Density } \\
\text { (individuals } / \mathrm{m}^{2} \text { ) }\end{array}$ & $\begin{array}{l}\text { Basal } \\
\text { cover }\end{array}$ & $\begin{array}{l}\text { R.F } \\
(\%)\end{array}$ & $\begin{array}{l}\text { R.DE } \\
(\%)\end{array}$ & $\begin{array}{r}\text { R.DO } \\
(\%)\end{array}$ & IVI & RVI \\
\hline & Grasses & & \multicolumn{8}{|c|}{$\left(\mathrm{mm}^{2} / \mathrm{m}^{2}\right)$} \\
\hline 1. & $\begin{array}{l}\text { Andropogon } \\
\text { virginicus }\end{array}$ & 3 & 2 & 0.06 & 0.61 & 0.71 & 0.46 & 0.29 & 1.46 & 0.48 \\
\hline 2. & Apluda mutica & 3 & 1.33 & 0.04 & 0.55 & 0.71 & 0.3 & 0.26 & 1.27 & 0.42 \\
\hline 3. & Brachiaria ramosa & 65 & 2.86 & 1.86 & 56.12 & 15.51 & 14.29 & 27.23 & 57.0 & 19 \\
\hline 4. & Chloris barbata & 58 & 3.63 & 2.11 & 29.21 & 13.84 & 16.21 & 14.17 & 44.22 & 14.74 \\
\hline 5. & Cynodon dactylon & 59 & 5.33 & 3.15 & 6.33 & 14.08 & 24.21 & 3.07 & 41.36 & 13.78 \\
\hline 6. & Digitaria eriantha & 3 & 1.66 & 0.05 & 0.12 & 0.71 & 0.38 & 0.05 & 1.14 & 0.38 \\
\hline 7. & $\begin{array}{l}\text { Eragrostis aspera } \\
\text { Heteropogon }\end{array}$ & 6 & 2.16 & 0.13 & 0.4 & 1.43 & 0.99 & 0.19 & 1.61 & 0.53 \\
\hline 8. & contortus & 3 & 1.66 & 0.05 & 0.12 & 0.71 & 0.38 & 0.05 & 1.14 & 0.38 \\
\hline
\end{tabular}




$\begin{array}{lll}\text { 9. } & \begin{array}{l}\text { Melinis repens } \\ \text { Pennisetum }\end{array} & 3 \\ \text { 10. } & \begin{array}{l}\text { alopecuroides } \\ \text { Perotis indica }\end{array} & 4 \\ \text { 11. } & \begin{array}{l}\text { Setaria pumila } \\ \text { 12. }\end{array} & \begin{array}{l}\text { Sporobolus } \\ \text { heterolepis } \\ \text { 13. }\end{array} \\ & \text { Sedges } & 48\end{array}$

1.66
2
1.4
2.86
3.93

0.05
0.08
0.07
0.43
1.89

\begin{tabular}{|c|c|c|c|c|c|}
\hline 0.1 & 0.71 & 0.38 & 0.04 & 1.13 & 0.37 \\
\hline 0.36 & 0.95 & 0.61 & 0.17 & 1.73 & 0.57 \\
\hline 0.37 & 1.19 & 0.53 & 0.17 & 0.89 & 0.29 \\
\hline 1.94 & 3.57 & 3.3 & 0.94 & 7.81 & 2.60 \\
\hline 4.8 & 11.4 & 14.52 & 2.32 & 18.24 & 6.08 \\
\hline 0.96 & 0.95 & 0.53 & 0.29 & 1.46 & 0.48 \\
\hline 0.9 & 0.23 & 0.15 & 0.43 & 0.81 & 0.27 \\
\hline 5.28 & 3.1 & 1.53 & 2.56 & 7.19 & 2.39 \\
\hline 2.49 & 2.38 & 1.15 & 1.20 & 4.73 & 1.57 \\
\hline 1.6 & 0.71 & 0.38 & 0.77 & 1.86 & 0.62 \\
\hline 3.84 & 0.73 & 0.07 & 1.86 & 2.66 & 0.88 \\
\hline 6.6 & 2.62 & 1.92 & 3.20 & 5.74 & 1.91 \\
\hline 2 & 0.73 & 0.07 & 0.97 & 1.77 & 0.59 \\
\hline 0.49 & 0.23 & 0.15 & 0.23 & 0.61 & 0.20 \\
\hline 2.17 & 0.47 & 0.23 & 1.05 & 1.75 & 0.58 \\
\hline 2.16 & 0.23 & 0.07 & 1.04 & 1.34 & 0.44 \\
\hline 0.95 & 0.47 & 0.15 & 0.46 & 1.08 & 0.36 \\
\hline 19.43 & 1.43 & 0.99 & 9.41 & 11.83 & 3.94 \\
\hline 0.78 & 2.14 & 1.92 & 0.37 & 4.43 & 1.47 \\
\hline 0.03 & 0.47 & 0.15 & 0.01 & 0.63 & 0.21 \\
\hline 0.09 & 0.47 & 0.15 & 0.04 & 0.66 & 0.22 \\
\hline 1.57 & 1.43 & 0.61 & 0.76 & 2.80 & 0.93 \\
\hline
\end{tabular}




\begin{tabular}{|c|c|c|c|c|c|c|c|c|c|c|}
\hline 31. & $\begin{array}{l}\text { Heliotrophium } \\
\text { indicum }\end{array}$ & 2 & 1.5 & 0.03 & 0.96 & 0.47 & 0.23 & 0.47 & 1.17 & 0.39 \\
\hline 32. & $\begin{array}{l}\text { Indigofera } \\
\text { enneaphylla }\end{array}$ & 5 & 1.8 & 0.09 & 2.89 & 1.19 & 0.69 & 1.40 & 3.28 & 1.09 \\
\hline 33. & $\begin{array}{l}\text { Justicia } \\
\text { tranquebariensis }\end{array}$ & 2 & 1.5 & 0.03 & 1.43 & 0.47 & 0.23 & 0.69 & 1.39 & 0.46 \\
\hline 34. & Lantana camara & 2 & 1.5 & 0.03 & 10.58 & 0.47 & 0.23 & 5.13 & 5.83 & 1.94 \\
\hline 35. & Martina annua & 1 & 2 & 0.02 & 0.81 & 0.23 & 0.15 & 0.39 & 0.77 & 0.25 \\
\hline 36. & $\begin{array}{l}\text { Meremmia } \\
\text { emarginata }\end{array}$ & 1 & 2 & 0.02 & 1 & 0.23 & 0.15 & 0.48 & 0.86 & 0.28 \\
\hline 37. & $\begin{array}{l}\text { Parthenium } \\
\text { hysterophorus }\end{array}$ & 23 & 1.43 & 0.33 & 14.96 & 5.48 & 2.53 & 7.26 & 15.27 & 5.09 \\
\hline 38. & $\begin{array}{l}\text { Peristrophe } \\
\text { bicalyculata }\end{array}$ & 2 & 1.5 & 0.03 & 0.84 & 0.47 & 0.23 & 0.40 & 11.0 & 3.66 \\
\hline 39. & Solanum torvum & 1 & 1 & 0.01 & 1.2 & 0.23 & 0.07 & 0.58 & 0.88 & 0.29 \\
\hline 40. & $\begin{array}{l}\text { Trichodesma } \\
\text { indicum }\end{array}$ & 3 & 1.66 & 0.05 & 2.38 & 0.71 & 0.38 & 1.15 & 2.24 & 0.74 \\
\hline 41. & $\begin{array}{l}\text { Tridax } \\
\text { procumbens }\end{array}$ & 11 & 1.63 & 0.81 & 38.68 & 2.62 & 6.22 & 4.16 & 13.0 & 4.33 \\
\hline 42. & Vernonia cinerea & 16 & 1.56 & 0.25 & 8.03 & 3.81 & 1.92 & 3.89 & 9.62 & 3.20 \\
\hline
\end{tabular}

R.F: Relative Frequency, R.DE: Relative Density, R.DO: Relative Dominance.

Table 9. Species composition in disturbed grassland: frequency, abundance, density and basal cover and their relative values with importance value index (IVI) and relative value of importance (RVI) during summer (April, 2015).

\begin{tabular}{|c|c|c|c|c|c|c|c|c|c|c|}
\hline \multirow[b]{2}{*}{ S.No } & \multirow[b]{2}{*}{ Species } & \multicolumn{4}{|c|}{ Quantitative attributes } & \multicolumn{5}{|c|}{ Synthetic attributes } \\
\hline & & $\begin{array}{c}\text { Frequency } \\
\text { (\%) }\end{array}$ & $\begin{array}{c}\text { Abundance } \\
\text { (individuals } / \mathbf{m}^{2} \text { ) }\end{array}$ & $\begin{array}{c}\text { Density } \\
\text { (individuals } / \mathbf{m}^{2} \text { ) }\end{array}$ & $\begin{array}{c}\text { Basal } \\
\text { cover } \\
\left(\mathrm{mm}^{2} / \mathrm{m}^{2}\right)\end{array}$ & $\begin{array}{l}\text { R.F } \\
(\%)\end{array}$ & $\begin{array}{l}\text { R.DE } \\
(\%)\end{array}$ & $\begin{array}{c}\text { R.DO } \\
(\%)\end{array}$ & IVI & RVI \\
\hline & Grasses & & & & & & & & & \\
\hline 1. & Andropogon virginicus & 3 & 1.33 & 0.04 & 0.4 & 1.22 & 0.59 & 0.36 & 2.17 & 0.72 \\
\hline 2. & Apluda mutica & 1 & 2 & 0.02 & 0.27 & 0.4 & 0.29 & 0.22 & 0.91 & 0.30 \\
\hline 3. & Brachiariaramose & 49 & 2 & 0.98 & 29.57 & 20 & 14.67 & 27.24 & 43.91 & 14.63 \\
\hline 4. & Chloris barbata & 31 & 3.51 & 1.09 & 15.09 & 12.65 & 16.31 & 13.90 & 42.86 & 14.28 \\
\hline
\end{tabular}




\begin{tabular}{|c|c|c|c|c|c|c|c|c|c|c|}
\hline 5. & Cynodon dactylon & 30 & 5.5 & 1.65 & 3.31 & 12.24 & 24.7 & 3.04 & 39.98 & 13.32 \\
\hline 6. & Digitaria eriantha & 2 & 1.5 & 0.03 & 0.07 & 0.81 & 0.44 & 0.06 & 1.31 & 0.43 \\
\hline 7. & Eragrostis aspera & 4 & 2.25 & 0.09 & 0.28 & 1.63 & 1.34 & 0.25 & 3.22 & 1.07 \\
\hline 8. & Heteropogon contortus & 1 & 2 & 0.02 & 0.05 & 0.4 & 0.29 & 0.04 & 0.73 & 0.24 \\
\hline 9. & Melinis repens & 2 & 1.5 & 0.03 & 0.06 & 0.81 & 0.44 & 0.05 & 1.3 & 0.43 \\
\hline 10. & Pennisetum alopecuroides & 3 & 1.66 & 0.05 & 0.22 & 1.22 & 0.74 & 0.20 & 2.16 & 0.72 \\
\hline 11. & Perotis indica & 2 & 2 & 0.04 & 0.21 & 0.81 & 0.59 & 0.19 & 1.59 & 0.53 \\
\hline 12. & Setaria pumila & 8 & 2.62 & 0.21 & 0.94 & 3.26 & 3.14 & 0.86 & 7.26 & 2.42 \\
\hline 13. & $\begin{array}{l}\text { Sporobolus heterolepis } \\
\text { Sedges }\end{array}$ & 31 & 3.58 & 1.11 & 2.82 & 12.65 & 16.61 & 2.59 & 31.85 & 10.61 \\
\hline 14. & $\begin{array}{l}\text { Cyperus rotundus } \\
\text { Forbs }\end{array}$ & 2 & 1.5 & 0.03 & 0.41 & 0.81 & 0.44 & 0.37 & 1.62 & 0.54 \\
\hline 15. & Acalypha indica & 1 & 1 & 0.01 & 0.45 & 0.4 & 0.14 & 0.41 & 0.95 & 0.31 \\
\hline 16. & Achyranthes aspera & 6 & 2.16 & 0.13 & 3.43 & 2.44 & 1.94 & 3.16 & 7.54 & 2.51 \\
\hline 17. & Alysicarpus monilifer & 6 & 1.66 & 0.1 & 1.66 & 2.44 & 1.49 & 1.52 & 5.45 & 1.81 \\
\hline 18. & Amaranthus spinosus & 2 & 1.5 & 0.03 & 0.96 & 0.81 & 0.44 & 0.88 & 2.13 & 0.71 \\
\hline 19. & Bidens pilosa & 1 & 1 & 0.01 & 0.38 & 0.4 & 0.14 & 0.35 & 0.89 & 0.29 \\
\hline 20. & Boerhaavia diffusa & 8 & 1.87 & 0.15 & 3.96 & 3.26 & 2.24 & 3.64 & 9.14 & 3.04 \\
\hline 21. & Calotropis gigantean & 1 & 1 & 0.01 & 2 & 0.4 & 0.14 & 1.84 & 2.38 & 0.79 \\
\hline 22. & Clitoria ternatea & 1 & 2 & 0.02 & 0.49 & 0.4 & 0.29 & 0.45 & 1.14 & 0.38 \\
\hline 23. & Croton bonplandianum & 1 & 1 & 0.01 & 0.72 & 0.4 & 0.14 & 0.66 & 1.2 & 0.40 \\
\hline 24. & Datura metal & 1 & 1 & 0.01 & 2.16 & 0.4 & 0.14 & 1.99 & 2.53 & 0.84 \\
\hline 25. & Eupatorium odoratum & 3 & 2.33 & 0.07 & 10.46 & 1.22 & 1.04 & 9.63 & 11.89 & 3.96 \\
\hline 26. & Euphorbia hirta & 5 & 3.8 & 0.19 & 0.59 & 2.04 & 2.84 & 0.54 & 5.42 & 1.80 \\
\hline 27. & E. microphylla & 1 & 2 & 0.02 & 0.03 & 0.4 & 0.29 & 0.02 & 0.71 & 0.23 \\
\hline 28. & Gomphrena decumbens & 2 & 1.5 & 0.03 & 0.58 & 0.81 & 0.44 & 0.53 & 1.78 & 0.59 \\
\hline 29. & Indigofera enneaphylla & 3 & 1.66 & 0.05 & 1.6 & 1.22 & 0.74 & 1.47 & 3.43 & 1.14 \\
\hline 30. & Justicia tranquebariensis & 1 & 1 & 0.01 & 0.47 & 0.4 & 0.14 & 0.43 & 0.97 & 0.32 \\
\hline
\end{tabular}




\begin{tabular}{|c|c|c|c|c|c|c|c|c|c|c|}
\hline 31. & Lantana camara & 2 & 1 & 0.02 & 7.05 & 0.81 & 0.29 & 6.49 & 7.59 & 2.53 \\
\hline 32. & Martynia annua & 1 & 1 & 0.01 & 0.4 & 0.4 & 0.14 & 0.36 & 0.90 & 0.30 \\
\hline 33. & Meremmia emarginata & 1 & 1 & 0.01 & 0.5 & 0.4 & 0.14 & 0.46 & 1.0 & 0.33 \\
\hline 34. & Parthenium histeroporus & 9 & 1.77 & 0.16 & 7.25 & 3.67 & 2.39 & 6.68 & 12.74 & 4.24 \\
\hline 35. & Peristrophe bicalyculata & 1 & 1 & 0.01 & 0.28 & 0.4 & 0.14 & 0.25 & 0.79 & 0.26 \\
\hline 36. & Trichodesma indicum & 1 & 2 & 0.02 & 0.95 & 0.4 & 0.29 & 0.87 & 1.56 & 0.52 \\
\hline 37. & Tridax procumbens & 9 & 1.22 & 0.11 & 5.25 & 0.67 & 1.64 & 4.83 & 7.14 & 2.38 \\
\hline 38. & Vernonia cinerea & 9 & 1.11 & 0.1 & 3.21 & 3.67 & 1.49 & 2.95 & 8.11 & 2.70 \\
\hline
\end{tabular}

F: Relative Frequency, R.DE: Relative Density, R.DO: Relative Dominance.

Table 10. Species composition in disturbed grassland: frequency, abundance, density and basal cover and their relative values with importance value index (IVI) and relative value of importance (RVI) during rainy (July, 2015).

\begin{tabular}{|c|c|c|c|c|c|c|c|c|c|c|}
\hline \multirow[b]{2}{*}{ S.No } & \multirow[b]{2}{*}{ Species } & \multicolumn{4}{|c|}{ Quantitative attributes } & \multicolumn{5}{|c|}{ Synthetic attributes } \\
\hline & & $\begin{array}{c}\text { Frequency } \\
(\%)\end{array}$ & $\begin{array}{c}\text { Abundance } \\
\text { (individuals } / \mathbf{m}^{2} \text { ) }\end{array}$ & $\begin{array}{c}\text { Density } \\
\text { (individuals } / \mathrm{m}^{2} \text { ) }\end{array}$ & $\begin{array}{c}\text { Basal cover } \\
\left(\mathrm{mm}^{2} / \mathrm{m}^{2}\right)\end{array}$ & $\begin{array}{l}\text { R.F } \\
(\%)\end{array}$ & $\begin{array}{c}\text { R.DE } \\
(\%)\end{array}$ & $\begin{array}{l}\text { Kat } \\
(\%)\end{array}$ & IVI & RVI \\
\hline & Grasses & & & & & & & & & \\
\hline 1. & Andropogon virginicus & 8 & 1.62 & 0.13 & 1.32 & 1.13 & 0.57 & 0.32 & 2.02 & 0.67 \\
\hline 2. & Apluda mutica & 5 & 1.6 & 0.08 & 1.1 & 0.71 & 0.35 & 0.27 & 1.33 & 0.44 \\
\hline 3. & Brachiariaramose & 79 & 3.98 & 3.15 & 95.05 & 11.22 & 13.88 & 23.7 & 48.8 & 16.26 \\
\hline 4. & Chloris barbata & 90 & 4.57 & 4.12 & 57.05 & 12.78 & 18.16 & 14.22 & 45.16 & 15.05 \\
\hline 5. & Cynodon dactylon & 79 & 6.55 & 5.18 & 10.4 & 11.22 & 22.83 & 2.59 & 36.64 & 12.21 \\
\hline 6. & Digitaria eriantha & 5 & 2.2 & 0.11 & 0.27 & 0.71 & 0.48 & 0.06 & 1.25 & 0.41 \\
\hline 7. & Eragrostis aspera & 11 & 2.45 & 0.27 & 0.84 & 1.56 & 1.19 & 0.2 & 2.95 & 0.98 \\
\hline 8. & Heteropogon contortus & 7 & 2.71 & 0.19 & 0.48 & 0.99 & 0.83 & 0.11 & 1.93 & 0.64 \\
\hline 9. & Melinis repens & 6 & 2.16 & 0.13 & 0.26 & 0.85 & 0.57 & 0.06 & 1.48 & 0.49 \\
\hline 10. & $\begin{array}{l}\text { Pennisetum } \\
\text { alopecuroides }\end{array}$ & 10 & 1.9 & 0.19 & 0.85 & 1.42 & 0.83 & 0.21 & 2.46 & 0.82 \\
\hline 11. & Perotis indica & 5 & 2 & 0.1 & 0.53 & 0.71 & 0.44 & 0.13 & 1.28 & 0.42 \\
\hline 12. & Setaria pumila & 30 & 2.96 & 0.89 & 4.02 & 4.26 & 3.92 & 1 & 9.18 & 3.06 \\
\hline
\end{tabular}




\begin{tabular}{|c|c|c|c|c|c|c|c|c|c|c|}
\hline 13. & $\begin{array}{l}\text { Sporobolus heterolepis } \\
\text { Sedges }\end{array}$ & 69 & 4.49 & 3.1 & 7.88 & 9.8 & 13.66 & 1.96 & 25.42 & 8.47 \\
\hline 14. & Cyperus rotundus & 15 & 1.73 & 0.26 & 3.6 & 2.13 & 1.14 & 0.89 & 4.16 & 1.38 \\
\hline & Forbs & & & & & & & & & \\
\hline 15. & Acalypha indica & 3 & 2 & 0.06 & 2.72 & 0.42 & 0.26 & 0.67 & 1.35 & 0.45 \\
\hline 16. & Achyranthes aspera & 18 & 1.66 & 0.3 & 7.92 & 2.55 & 1.32 & 1.97 & 5.84 & 1.94 \\
\hline 17. & Alysicarpus monilifer & 18 & 1.77 & 0.32 & 5.31 & 2.55 & 1.41 & 1.32 & 5.28 & 1.76 \\
\hline 18. & Amaranthus spinosus & 4 & 2.5 & 0.1 & 3.21 & 0.56 & 0.44 & 0.8 & 1.8 & 0.6 \\
\hline 19. & Bidens pilosa & 1 & 2 & 0.02 & 0.76 & 0.14 & 0.08 & 0.18 & 0.4 & 0.13 \\
\hline 20. & Boerhaavia diffusa & 29 & 1.44 & 0.42 & 11.09 & 4.11 & 1.85 & 2.76 & 8.7 & 2.9 \\
\hline 21. & Calotropis gigantean & 4 & 1 & 0.04 & 8.03 & 0.56 & 0.17 & 2 & 2.73 & 0.91 \\
\hline 22. & Cleome pentaphylla & 1 & 1 & 0.01 & 0.19 & 0.14 & 0.04 & 0.04 & 0.22 & 0.07 \\
\hline 23. & Clitoria ternatea & 3 & 1.66 & 0.05 & 1.23 & 0.42 & 0.22 & 0.3 & 0.94 & 0.31 \\
\hline 24. & Coccinia indica & 2 & 1 & 0.02 & 0.27 & 0.28 & 0.08 & 0.06 & 0.42 & 0.14 \\
\hline 25. & Crotalaria verrucosa & 1 & 1 & 0.01 & 0.98 & 0.14 & 0.04 & 0.24 & 0.42 & 0.14 \\
\hline 26. & Croton bonplandianum & 6 & 1.33 & 0.08 & 5.78 & 0.85 & 0.35 & 1.44 & 2.64 & 0.88 \\
\hline 27. & Datura metal & 3 & 1 & 0.03 & 6.48 & 0.42 & 0.13 & 1.61 & 2.16 & 0.72 \\
\hline 28. & Erigeron annus & 3 & 1.33 & 0.04 & 1.91 & 0.42 & 0.17 & 0.47 & 1.06 & 0.35 \\
\hline 29. & Eupatorium odoratum & 13 & 1.69 & 0.22 & 32.88 & 1.84 & 0.97 & 8.19 & 11 & 3.66 \\
\hline 30. & Euphorbia hirta & 13 & 2.76 & 0.36 & 1.13 & 1.84 & 1.58 & 0.28 & 3.7 & 1.23 \\
\hline 31. & E. microphylla & 4 & 1.5 & 0.06 & 0.09 & 0.56 & 0.26 & 0.02 & 0.84 & 0.28 \\
\hline 32. & Evolvulus nummularis & 3 & 2 & 0.06 & 0.27 & 0.42 & 0.26 & 0.06 & 0.74 & 0.24 \\
\hline 33. & Gomphrena decumbens & 10 & 1.5 & 0.15 & 2.94 & 1.42 & 0.66 & 0.73 & 1.42 & 0.47 \\
\hline 34. & Heliotrophium indicum & 7 & 1.28 & 0.09 & 2.89 & 0.99 & 0.39 & 0.72 & 2.81 & 0.93 \\
\hline 35. & Hibiscus vitifolius & 1 & 1 & 0.01 & 1.24 & 0.14 & 0.04 & 0.3 & 0.48 & 0.16 \\
\hline 36. & Indigofera enneaphylla & 8 & 2 & 0.16 & 5.14 & 1.13 & 0.7 & 1.28 & 3.11 & 1.03 \\
\hline 37. & Ipomea obscura & 2 & 1 & 0.02 & 1.44 & 0.28 & 0.08 & 0.35 & 0.71 & 0.23 \\
\hline 38. & Justicia tranquebariensis & 3 & 1.66 & 0.05 & 2.38 & 0.42 & 0.22 & 0.59 & 1.23 & \\
\hline
\end{tabular}




\begin{tabular}{|c|c|c|c|c|c|c|c|c|c|c|}
\hline 39. & Lantana camera & 4 & 1.25 & 0.05 & 17.64 & 0.56 & 0.22 & 4.39 & 5.17 & 1.72 \\
\hline 40. & Macrotyloma uniflorum & 1 & 2 & 0.02 & 0.76 & 0.14 & 0.08 & 0.18 & 0.4 & 0.13 \\
\hline 41. & Martynia annua & 2 & 1.5 & 0.03 & 1.22 & 0.28 & 0.13 & 0.3 & 0.71 & 0.23 \\
\hline 42. & Meremmia emarginata & 3 & 1.66 & 0.05 & 2.51 & 0.42 & 0.22 & 0.62 & 1.26 & 0.42 \\
\hline 43. & M.tridentate & 1 & 2 & 0.02 & 0.9 & 0.19 & 0.08 & 0.22 & 0.05 & 0.01 \\
\hline 44. & $\begin{array}{l}\text { Parthenium } \\
\text { hysterophorus }\end{array}$ & 46 & 1.73 & 0.8 & 36.27 & 6.53 & 3.52 & 9 & 19.05 & 6.35 \\
\hline 45. & Pavonia indicum & 1 & 1 & 0.01 & 3.84 & 0.14 & 0.04 & 0.95 & 1.13 & 0.37 \\
\hline 46. & Peristrophe bicalyculata & 5 & 1.4 & 0.07 & 1.97 & 0.71 & 0.3 & 0.49 & 1.5 & 0.5 \\
\hline 47. & Solanum torvum & 2 & 1.5 & 0.03 & 3.62 & 0.28 & 0.13 & 0.9 & 1.31 & 0.43 \\
\hline 48. & Spermacoce hispida & 1 & 2 & 0.02 & 1.76 & 0.14 & 0.08 & 0.43 & 0.65 & 0.21 \\
\hline 49. & Trichodesma indicum & 8 & 2 & 0.16 & 7.64 & 1.13 & 0.7 & 1.9 & 3.73 & 1.24 \\
\hline 50. & Tridax procumbens & 25 & 1.52 & 0.38 & 18.14 & 3.55 & 1.67 & 4.52 & 9.74 & 3.24 \\
\hline 51. & Vernonia cinerea & 26 & 1.76 & 0.46 & 14.79 & 3.69 & 2.02 & 3.68 & 9.39 & 3.13 \\
\hline
\end{tabular}

R.F: Relative Frequency, R.DE: Relative Density, R.DO: Relative Dominance.

Table - 11. Similarity index (SI) and frequency index community coefficient ( FICC) obtained for the study sites during three different seasons.

\begin{tabular}{|c|c|c|c|c|}
\hline S.No. & Season & \multicolumn{3}{|c|}{ Attributes } \\
\hline 2. & Summer & 0.63 & 96.26 & \\
\hline 3. & Rainy & 0.83 & 94.30 & \\
\hline
\end{tabular}

Table 12. Simpson index of dominance and Shanno-Wiener's index of diversityfor the study sites during three different seasons.

\begin{tabular}{|c|c|c|c|c|c|c|c|}
\hline \multirow{2}{*}{ S.No } & \multirow{2}{*}{ Study sites } & \multicolumn{6}{|c|}{ Attributes } \\
\hline & & & Dominance & & & -Wiener's & sity \\
\hline \multirow{2}{*}{1.} & \multirow{2}{*}{ Undisturbed } & Winter & Summer & Rainy & Winter & Summer & Rainy \\
\hline & & 0.14 & 0.12 & 0.13 & 1.72 & 1.5 & 1.44 \\
\hline 2. & Disturbed & 0.12 & 0.10 & 0.09 & 1.78 & 1.74 & 1.7 \\
\hline
\end{tabular}


Table 13. Combined Disturbance Index (out of 30) scored by the study sites.

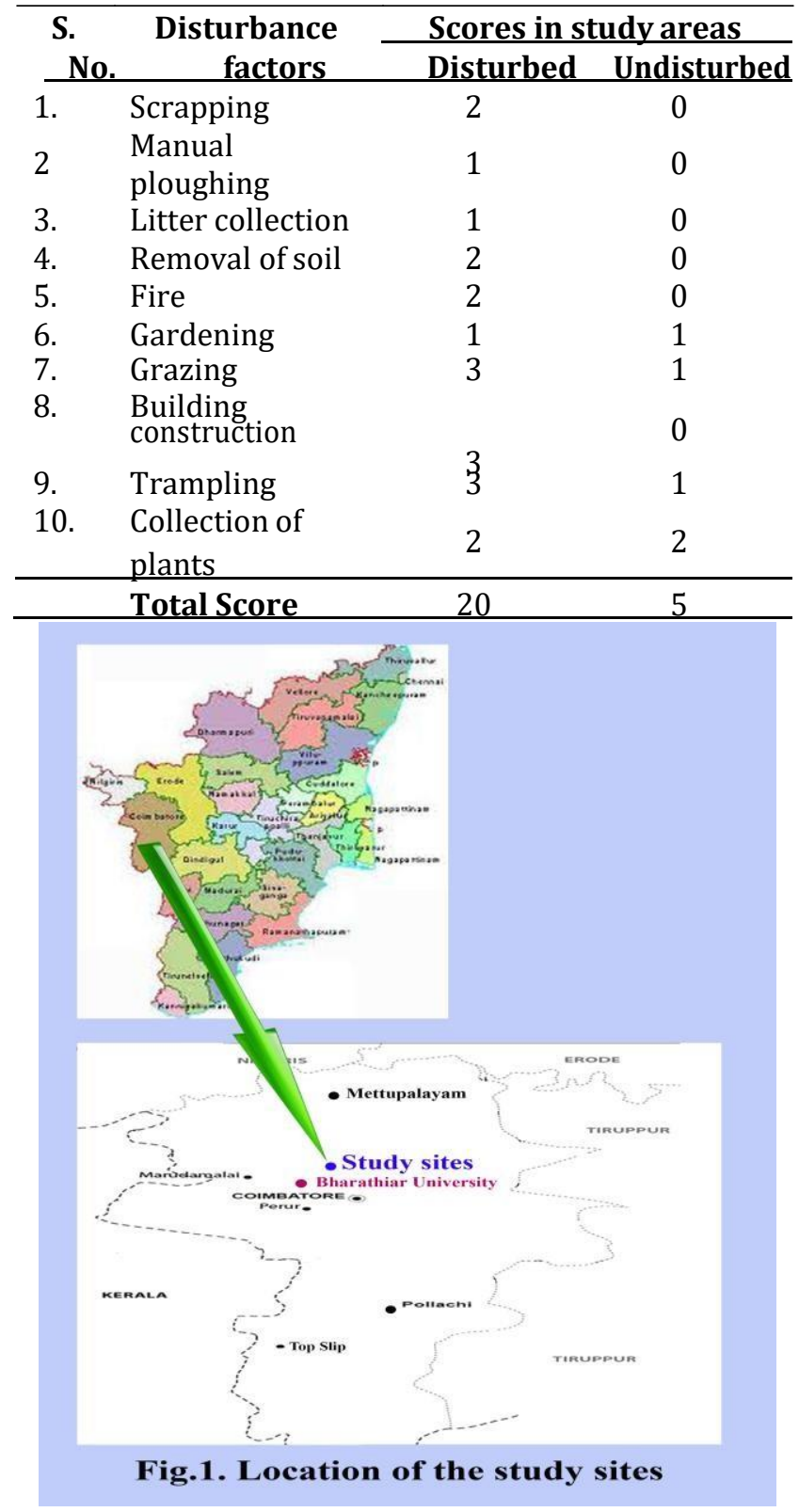

Of the various plant species available in the two different study areas, the grass species Brachiaria ramosa secured the highest value of IVI of above 49.86 in undisturbed site (Figs. 2-4). The same species also showed its higher ecological importance in undisturbed site by securing higher IVI of more than 43.91 (Figs. 5-7). The other species like Boerhaavia diffusa, Cynodon dactylon and Parthenium hystoporous were also showing higher IVI in both sites. The species of least significance (lowest IVI) was varied in both sites across the seasons studied (Figs. 8-11). In undisturbed site, the species such as Ipomea dissecta and Phyllanthus amarus, Merremia emarginata and Coccinia indica were present with lowest IVI during winter, summer and rainy season respectively. In disturbed site, the species such as Clitoria ternatea, Heteropogon contortus and Merremia tridenteta were secured lowest IVI during winter, summer and rainy season respectively. Based on the IVI score made by these species, it is understood that these are poorly established species in the communities of the study sites.

The resource apportionment for the various species present during different seasons is explained by dominance - diversity curves (Figs. 8-10 and 1113 respectively for undisturbed site and disturbed site). For both sites the geometric curve obtained exhibited that single species dominance was more pronounced during all seasons. The dominant species, Brachiaria ramosa received the higher impact of environment and could able to draw more resources from both the study sites.

The similarity index between the two sites studied for the respective seasons is given in Table 11. The species composition was determined to be more highly similar (83\%) during rainy season between the two sites. However, during winter and summer also the similarity was above $60 \%$. This fact showed that both the study areas were originally contained similar species composition. However, due to disturbance factor, the composition of the species has been changed.

Many constituent species in both study sites have established very poorly, based on their distribution level, density and the ecological importance (Tables 5-10). The grass species such as Melines repens, Perotis indica, Andropogon virgincus and Apluda mutica and the forbs such as Coccinia indica, Oldenlandia umbellata, Passiflora foetida and Cleome pentaphylla have scored very lower values of frequency, density, basal cover and importance value index in the undisturbed site. Therefore, these species are requiring special care to increase their population in undisturbed study site. Similarly, in disturbed study site also, many species were present with poor perpetuation. The grass species such as Apluda mutica, Digera arvensis, Melines repens and Perotis indica and the forbs like Cleome pentaphylla, Hibiscus vitifolius, Merremia tridentate and Spermacoce hispida have occurred with least ecological perpetuation, as they obtained very lower values for quantitative ecological characters. Therefore these species also need special care for protection.

On basis of frequency index community coefficient (FICC), it is known that both the study sites were homogenous to each other (>94\% FICC) at all 
seasons (Table 12). The dominance index obtained in both sites is less than 0.14 . So both sites are not dominated by any single species on basis of number of individuals contributed (Table 12). The ShannonWiener's index of diversity obtained for the two study areas is given in Table 12 . As the index value was around 1.5 in both study areas during all the three studied seasons, the diversity of species was not note worthy. This score showed that both the study sites were not having contusive environment for the development of saturated community.

The combined disturbance index (CDI) scored by the two sites is presented in the Table 13 . It exhibited that the disturbed site scored $20 \mathrm{CDI}$ whereas, undisturbed site scored only 5 CDI. It is known from this fact that the disturbed site studied was highly influenced by many external factors including anthropogenic disturbances due to which many of the species lost in the disturbed site.

\section{DISCUSSION}

The effect of disturbance on the changes in species composition and certain quantitative ecological attributes of the constituent species in Brachiaria ramosa dominated grassland were studied for a period of one year. The temperature data shows that there are no well marked seasons in the study area. The differences between summer and winter minimum temperatures were ranging between 4 and $5^{\circ} \mathrm{C}$ only. The maximum of that was varying from 6 to $8^{\circ} \mathrm{C}$ only. It is of common fact that in tropical climatic zone, the seasons are not marked well. The rainfall and humidity data exhibited that the study area is having semi-arid habitats which are mainly constituted by mesophytes and zerophytes.

The development of vegetation in terms of the number of individuals in the study area is directly proportional to rainfall. The grasslands of the present study area are having abundant number of individuals of various plant species during southwest monsoon and north-east monsoon months (July - August and October - December respectively). It indicates that the rainfall is the limiting factor mainly influenced in the community development. It is well known that in tropical climatic areas water is the limiting factor as the other climatic factors like intensity of light, photoperiod, humidity, temperature, etc are available enormously, except the rainfall which is occurring during seasons only.

Among the 71 species available altogether in both study sites, a higher number of 66 species $(92 \%)$ possessed medicinal uses. It indicates the potentiality of study area for the inhabitation of medicinal plants. It may be explained that the semiarid condition with water stress during most of the months in a year can induce the plant species to produce secondary metabolites as defence mechanism against water stress (Frank et al., 2012; Elisa et al., 2013). The uses of species for diverse medicinal purposes show the production of different kinds of secondary metabolites with rich varieties of bioactive compounds in the study sites.

Phytosociological analysis of a plant community is the first and foremost basis of the study of any piece of vegetation as it is a prerequisite for the understanding of community structure and organization. The appearance of a plant community is largely dependent upon the lifeform of the dominant plants, classification based on the criteria given by Raunkiar (1934) who gave different terms to designate different types of lifeforms. In the present study, the life-form classes indicate a chamaephytic flora. This supports the view that the herbaceous flora mainly composed by annuals and fresh vegetative growth takes place every rainy season (Ambasht, 1987). But the usefulness of the Raunkiaer's biological spectrum as indicative of climatic condition is limited as the other ecological factors such as biotic disturbances are not taken into account. The present study area also met with certain biotic disturbances like mild grazing and construction attempts.

For understanding the community structure and organization, species composition is foremost requisite. Species composition is one of the major characters of plant community (Dansereau, 1960). It is evident from the data that the study area comprised a considerable number of herbs among them, forbs contributed more species than grasses. However, the number of individuals contributed by the grass was considerably higher than the forbs. This may be attributed to the presence of wide ecological amplitude in grasses (Misra, 1980; Manorama, 1996).

Of the 71 and 51 species present in the undisturbed and disturbed study sites respectively, the grasses like Brachiaria ramosa, Cynodon dactylon, Chloris barbata and Sporobolus heterolepis and the forbs like Boerhaavia diffusa, Achyranthes aspera, Parthenium hysterophorus and Alysicarpus monilifer in undisturbed site and in disturbed site in addition to these forbs, Euphorbia hirta and Tridax procumbens were distributed evenly by securing more than $70 \%$ frequency value. According to Misra (1980) this may be attributed to their high reproductive capacity, quick dispersal of seeds and wind pollination to produce viable seeds. Due to the 
lacking of these attributes, the other constituent species may show poor distribution.

In addition to higher distribution, these grasses and forbs in the two study sites were present with higher density and basal cover also. Shantz (1954) opined that the presence of tolerance to poor conditions, adaptability and suit various ecological niches for certain grass species could be the possible reasons for the successful establishment in the grasslands as the dominant and important grasses.

In both study sites many species registered lower values of frequency, density and basal cover and hence the importance value index. They are the grass species such as Melinis repens, Perotis indica, Andropogon virginicus, Apluda mutica and the forbs such as Coccinia indica, Oldenlandia umbellata, Pasiflora foetida and Cleome pentaphylla. The poor distribution mechanism, less seed output and lower viability of seeds may be the factor responsible for the weaker establishment of the above mentioned species in the studied sites (Paulsamy, et al., 2008).

It was further observed that a sizable number of 20 species such as Abutilon indicum, Aerva lanata, A. tomentosa, Alternanthera pungens, A. sessilis, Boerhaavia erecta, Cardiospermum halicacabum, Commelina benghalensis, Corchorus tridens, Euphorbia hirta, Evolvulus alsinoides, Ipomea dissecta, Leucas aspera, Mirabilis jalapa, Oldenlandia umbellata, Pasiflora foetida, Phyllanthus amarus, P. maderaspatensis and Plumbago zeylanica have disappeared in distributed site. This may be due to poor adaptability of these species against the disturbance caused in the disturbed site. Gunaga et al. (2013) also observed the same trend of disappearance of many species in disturbed site as their adaptive variations are determined to be not enough for survival.

Despite the dominance exerted by the grass species, Brachiaria ramosa, the dominance index obtained in both sites showed that there was no single species dominance in the study area. This contradiction may be due to the number of individuals contributed by all the remaining species altogether was greater than the total number of individuals contributed by the single species, Brachiaria ramosa. However, the resource apportionment by the individual species indicates (Figs. 8-13) that the communities were dominated by single species. Therefore, the functional behaviour of individual species in terms of community metabolism was playing major role in deciding the species importance in the present study areas rather than the numerical strength contributed to communities. This fact is at par with the generalizations made for community metabolism and stability of ecosystem in majority of natural communities at global level (McNaughton, 1985).

The combined disturbance index scored by disturbed site (Table 13) indicates that this site was severely influenced by anthropogenic disturbances which resulted in the drastic changes in species composition and community organization. It is quite clear that greater protection leads to better regeneration of community. From the commercial point of view, these studied grasslands are valuable as they contain many medicinal and other economically important plants. Repeated annual fires, continued grazing, scraping, collection of medicinal plants and other anthropogenic disturbances resulted in the low regeneration as well as low density of the vegetation. Varghese and Menon (1998), Hedge et al. (2005), Gunaga et al. (2013) have also reported the effect of human disturbance on the community composition and possible management practices to be followed for the effective regeneration of the vegetation.

\section{CONCLUSION}

In conclusion, it is suggested that the studied Brachiaria ramosa dominated grassland near Bharathiar University must be given conservation priority to protect the valuable medicinal species. Despite the seasonal changes, the anthropogenic disturbances were determined to be most influencing factor to affect the species composition and the quantitative ecological attributes of many sensitive species. Therefore, construction activities, over grazing by domestic animals, fire, scraping, collection of medicinal plants etc must be checked so as to protect the species in their habitats. Further, ecosystem - specific management plans must be developed to protect the individual species and the grassland community as well. Protection of such natural grassland will also aid in the regulation of ecological process like energy flow, food chain and food web and cycling of materials which would results in ecological balance and stability of ecosystem.

\section{REFERENCES}

Ambasht R.S., (1987). On the fragility of sloping land ecosystem. in : Sharma M.R., Gupta B.K., (Eds) proc. U.G.C. Symp. Recent Advances in Plant Science; pp. 344-354.

Armstrong S.F., (1907). The botanical and chemical composition of herbage pastures and meadows. J. Agr. Sci. 2, 283-304. 
Bor N.L., (1938). The vegetation of the Nilgiris . Ind. For. 64, 600-609.

Dansereau P., (1960). The origin and growth of plant communities. in: Growth in living systems. Int. Symp., Purudue Univ., Newyork; pp. 576-603.

Davies W., (1960). The grass crop. 2nd (Eds). E. and F.N. Spon Ltd., London.

Elisa P., B. Enrico, Z. Marco, P. Carlo, B. Alberto, P. Sonia and V. Angelo, (2013). Plant FlavonoidsBiosynthesis, Transport and Involvement in Stress Responses. Int. J. Mol. Sci. 14: 1495014973.

Frank C., M. Pride and N. Casper, (2012). Biologically Based Methods for Pest Management in Agriculture under Changing Climates: Challenges and Future Directions. Insects 3: 1171-1189.

Gilmanov T.G., L. Aires, Z. Barcza, V.S. Baron, L. Belelli and J.D. Beringer, (2010). Productivity, respiration, and light-response parameters of world grassland and agroecosystems derived from flux-tower measurements. Rangel. Ecol. Manag. 63(1), 16-39.

Griez-Smith P., (1964). Quantitative plant ecology $2^{\text {nd }}$ (Eds.), Butterworths, London.

Gunaga S., N. Rajeshwari and R. Vasudevan, (2013). Tree diversity and disturbance of Kaan forests: Relics of a community protected climax vegetation in the Central Western Ghats. Trop. Ecol. 54(1), 117-131.

Hedge G.T., K.S. Murali, D.M. Bhat, P.R. Bhat and N.H. Ravindranath, (2005). Effect of protection of regeneration in some selected village forests under community protection in Uttara Kannada district, Karnataka, India. Curr. Sci. 88: 10.

Manorama, S., (1996). Studies on the natural regeneration of lime mined sites at Madukkarai, Coimbatore District, Tamil Nadu, India. Ph.D. Thesis, Bharathiyar University, Coimbatore, India.

Margelf, R., (1968). Perspectives in ecological theory. Univ. of Chicago press. p.112.

McNaughton, S.J., (1985). Ecology of grazing ecosystem: The Serengheti. Ecol. Monogr. 55: 259-294.
Meher-Homiji, V.M., (1969). Some considerations on the sucession of vegetation around Kodaikanal. J. Indian Bot. Soc. XLVIII, 42-51.

Misra, K.C., (1980). Manual of Plant Ecology, Oxford and IBH publishing co., New Delhi, Bombay and Calcutta. p. 457.

Misra, R., (1968). The study of tropical vegetation in Madhya Pradesh and the Gangatic valley. Proc. Kandy Symp. Study of Tropical vegetation, UNESCO; pp. 74-83.

Moore, C.W.E., (1964). Grasses and grasslands (Eds.) Barnard G., Chapter 11, MaCmillian, London.

Paulsamy S., K.K. Vijay Kumar, M. Murugesan, M. Sivashanmugam, P. Senthil Kumar and D. Suresh, (2008). Author, Medicinal and other Economic Plants of Shola Understories, the Nilgiris, Western Ghats. International Book Distributors, Dehradun.

Ranganathan, C.R., (1938). Studies in the ecology of shoal grassland vegetation of the Nilgiris Plateau. Ind. For. 64, 523-541.

Raunkiar, S., (1934). The life forms of plants and statistical plant geography. Clarendon Press, Oxford.; p. 639.

Shantz, H.L., (1954). The place of grassland in the earth's cover of vegetation. Ecology. 35: 143145.

Simpson, E.H., (1949). Measurement of diversity. Nature. 163: 688.

Speeding, C.R.W., (1976). Grassland Ecology. Oxford, University Press, Oxford.; p. 221.

Stapledon, R.G., (1913). Pasture problems and drought resistance. J. Agric. Sci. 5: 129-151.

Stove W.C. and Fryer J.R.A., (1935). A botanical study of pasture mixtures. Sci. Agric. 15: 777-805.

Thomas, A.S., (1960). Proc.IX Int. Grassland Congress. pp. 405-407.

Varghese, A.O., A.R.R. Meon, (1998). Vegetation characteristic of southern moist mixed deciduous forests of Agasthyamalai region of Kerala. Ind. J. Forestry. 21: 337-344.

White R., S. Murray and M. Rohweder, (2000). Plant Analysis of Global Ecosystems: Grassland ecosystems. World Resources Institute, Washington, DC. 